$1-1-1975$

\title{
The West Virginia University Forest Climate Station at Coopers Rock
}

Richard Lee

Stephen C. Hill

Follow this and additional works at: https://researchrepository.wvu.edu/ wv_agricultural_and_forestry_experiment_station_bulletins

\section{Digital Commons Citation}

Lee, Richard and Hill, Stephen C., "The West Virginia University Forest Climate Station at Coopers Rock" (1975). West Virginia Agricultural and Forestry Experiment Station Bulletins. 642T.

https://researchrepository.wvu.edu/wv_agricultural_and_forestry_experiment_station_bulletins/716 @ WVU. It has been accepted for inclusion in West Virginia Agricultural and Forestry Experiment Station Bulletins by an authorized administrator of The Research Repository @ WVU. For more information, please contact ian.harmon@mail.wvu.edu. 


\section{The West Virginia University Forest Climate Station at Coopers Rock}

Bulletin 642T September 1975

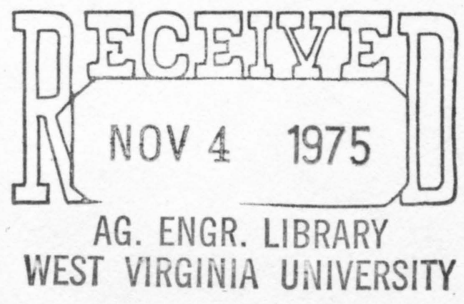

Nest Virginia University Agricultural Experiment Station

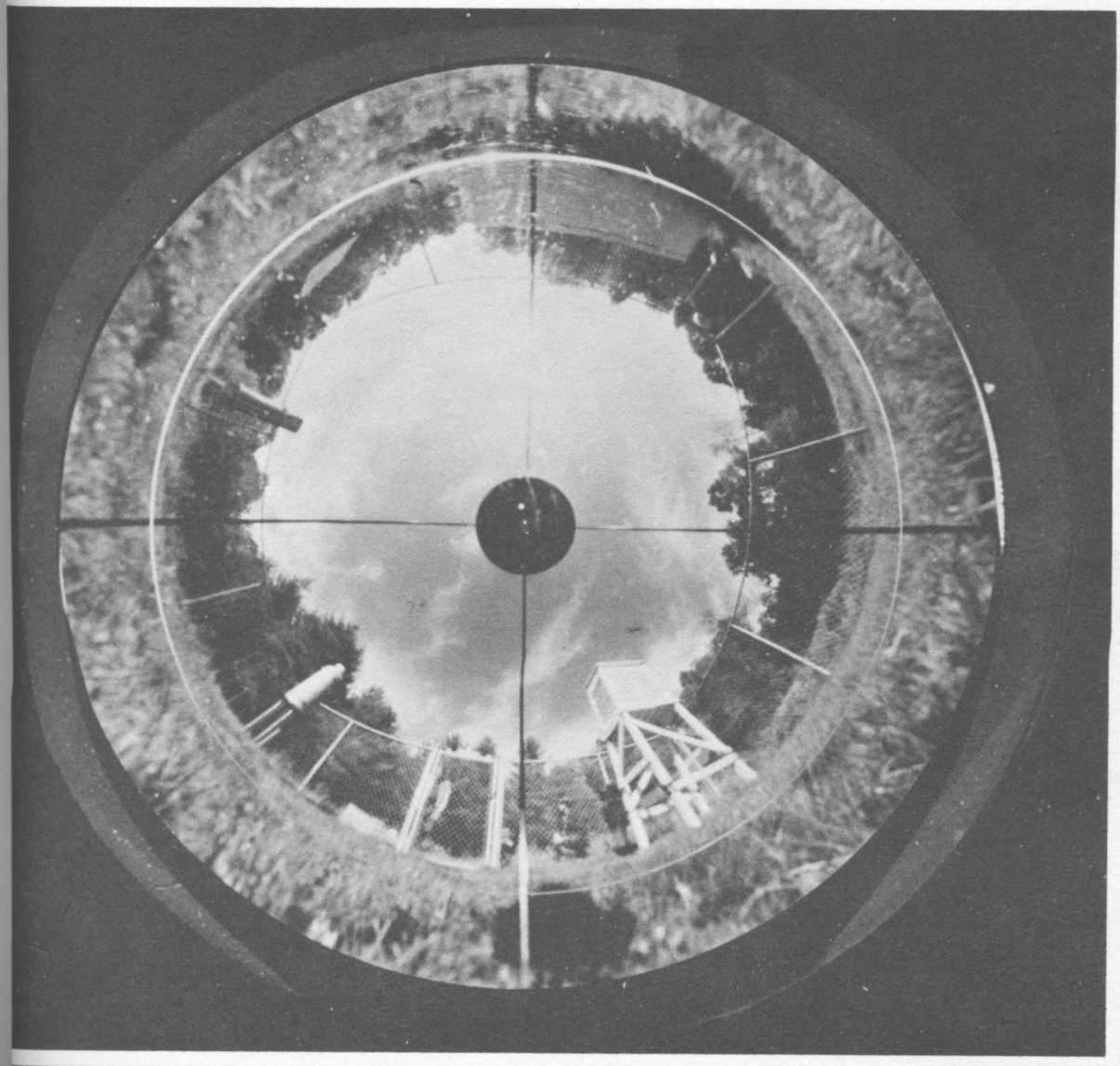




\title{
AUTHORS
}

Richard Lee is forest scientist, Division of Forestry, West Virginia University Agricultural Experiment Station, and Stephen C. Hill is research technician, Division of Forestry.

\author{
WEST VIRGINIA UNIVERSITY \\ AGRICULTURAL EXPERIMENT STATION \\ COLLEGE OF AGRICULTURE AND FORESTRY \\ DALE W. ZINN, DIRECTOR \\ MORGANTOWN
}


Contents

SUMMARY AND CONCLUSIONS / iii

THE NEED / 1

STATION HISTORY, DESCRIPTION / 1

OBSERVATIONS / 6

STATION COMPARISONS / 6

Precipitation / 7

Air Temperature / 11

ADDITIONAL FOREST CLIMATE DATA / 16

Evaporation and Wind / 16

Humidity / 17

LITERATURE CITED / 27 
Blank Page in Original Bulletin 


\section{SUMMARY AND CONCLUSIONS}

Climatological observations at the University Forest Climate Station show that data from outlying stations do not adequately characterize the Forest climate. As additional years of data are accumulated, more definitive interpretations will be possible. On the basis of the two-year record, it is clear that:

1. Total annual precipitation at Coopers Rock is about 33 per cent greater than at Morgantown, and about 17 per cent greater than at Brandonville. The orographic (elevation difference) effect does not adequately explain the observed differences; greater protection from wind at the Forest Station (smaller gage errors) appears to be a more probable cause.

2. Relative precipitation amounts at the outlying stations vary markedly with the season; they are greater during the warmer part of the year.

3. Total annual snowfall at Coopers Rock is at least twice as great as that at Morgantown.

4. Mean annual air temperature at the Forest Station is slightly higher than expected, relative to the outlying stations, based on average temperature lapse rates in West Virginia. Mean monthly summer temperatures are lower than expected, but winter temperatures are considerably higher.

5. The seasonal trends of average monthly maximum and minimum air temperatures at the Forest are similar to that of the monthly means, but deviations are more pronounced with regard to the maxima.

6. The absolute monthly maxima are almost always lowest at Coopers Rock. The absolute minima at the Forest are generally intermediate between those at the outlying stations.

7. Maximum temperatures above $75^{\circ} \mathrm{F}$ occur with much greater frequency at the outlying stations.

8. The annual temperature range at the Forest Station is generally smaller than at the outlying stations, as are the monthly and diurnal ranges, especially during late summer and autumn. Interdiurnal changes in mean air temperature are lowest at the Forest, especially during the summer months.

9. In spite of its greater elevation, the length of the freeze-free period at Coopers Rock is greater than, or about equal to, the periods at outlying stations.

10. Pan evaporation rates at the Forest Station average about 0.1 inches per day during the growing season. Average daily maximum and minimum relative humidities are about 84 and 57 per cent during January, and 97 and 48 per cent during July. The mean vapor pressure is about $4.7 \mathrm{mb}$ during January, and 16.0 mb during July. 
Blank Page in Original Bulletin 


\title{
The West Virginia University Forest Climate Station at Coopers Rock
}

\author{
by Richard Lee and Stephen C. Hill
}

\section{THE NEED}

Forestry related research has been in progress at the West Virginia University Forest (Coopers Rock State Forest) for about 40 years. During that period the Division has grown rapidly and, with the adoption of a graduate program in 1962, field research activities at the Forest have intensified. The spectrum of research activity has expanded simultaneously and now includes forest biometry, economics, silviculture, genetics, hydrology, meteorology, wildlife ecology, and recreation. In addition, other University faculties and government agencies have used the Forest as an outdoor laboratory.

Field research, whether it involves the growth and harvesting of wood products, the behavior of wildlife, recreation and aesthetic appreciation, or the physical and ecological influences of forest cover, is intimately and inextricably associated with the averages and eccentricities of atmospheric phenomena. In the past, researchers at the University Forest have relied heavily on weather information obtained from stations outside the Forest (i.e., at Brandonville and Morgantown). In 1972, a station was established at the Forest Headquarters for the purposes of (1) obtaining a consistent long-term endemic record, and (2) comparing the Forest climate with climates at other stations.

\section{STATION HISTORY, DESCRIPTION}

The Coopers Rock Climate Station is located on Chestnut Ridge (Figure 1), along the Sand Springs Road, 1.5 miles north of State Route 73, at an elevation of 2,275 feet. The terrestrial coordinates of the station are $39^{\circ} 40^{\prime} 37^{\prime \prime}$ North Latitude and $79^{\circ} 46^{\prime} 20^{\prime \prime}$ West Longitude. It is roughly equidistant from Brandonville (11 miles to the east) and Morgantown ( 8 miles to the west). The elevation of the Station at Brandonville is 1,798 feet, and at Morgantown 1,245 feet.

The Station was established in conformance with National Weather Service criteria (U. S. Department of Commerce, 1970). National Weather Service personnel inspected and approved the site in 1972, before the instrumentation was installed. A substation network specialist visits the Station annually to inspect and service the instruments.

During the summer of 1972, the site (Figure 2) was cleared of all woody vegetation and leveled. Velva green grass was sown within the Station boundaries, and Kentucky-31 fescue was sown in the circumambient clearing. Periodic applications of Tordon $10 \mathrm{~K}$ and Fenuron were used to inhibit sprout growth in the clearing. 


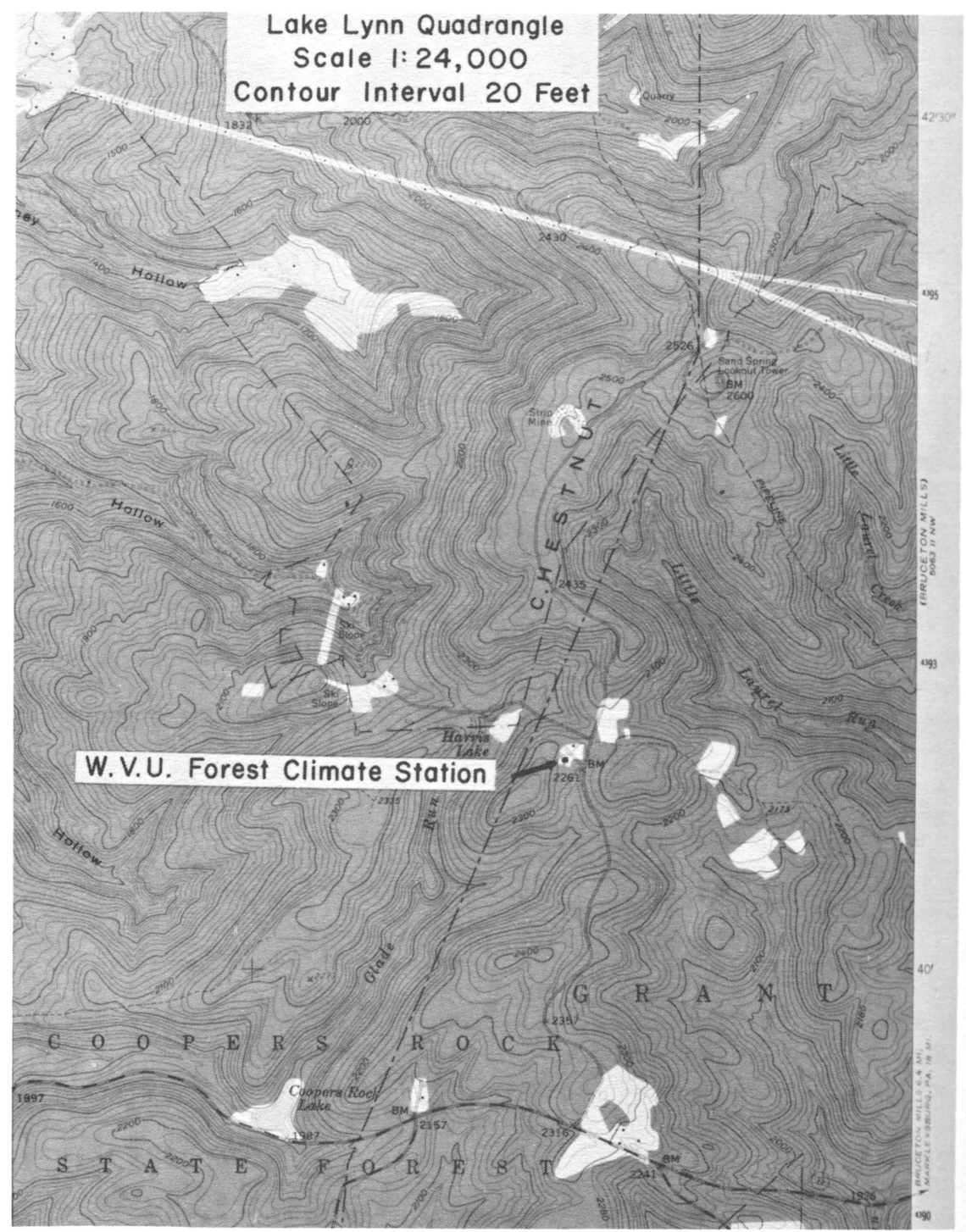

Figure 1. Topographic map of Chestnut Ridge showing location of the Forest Climate Station. 


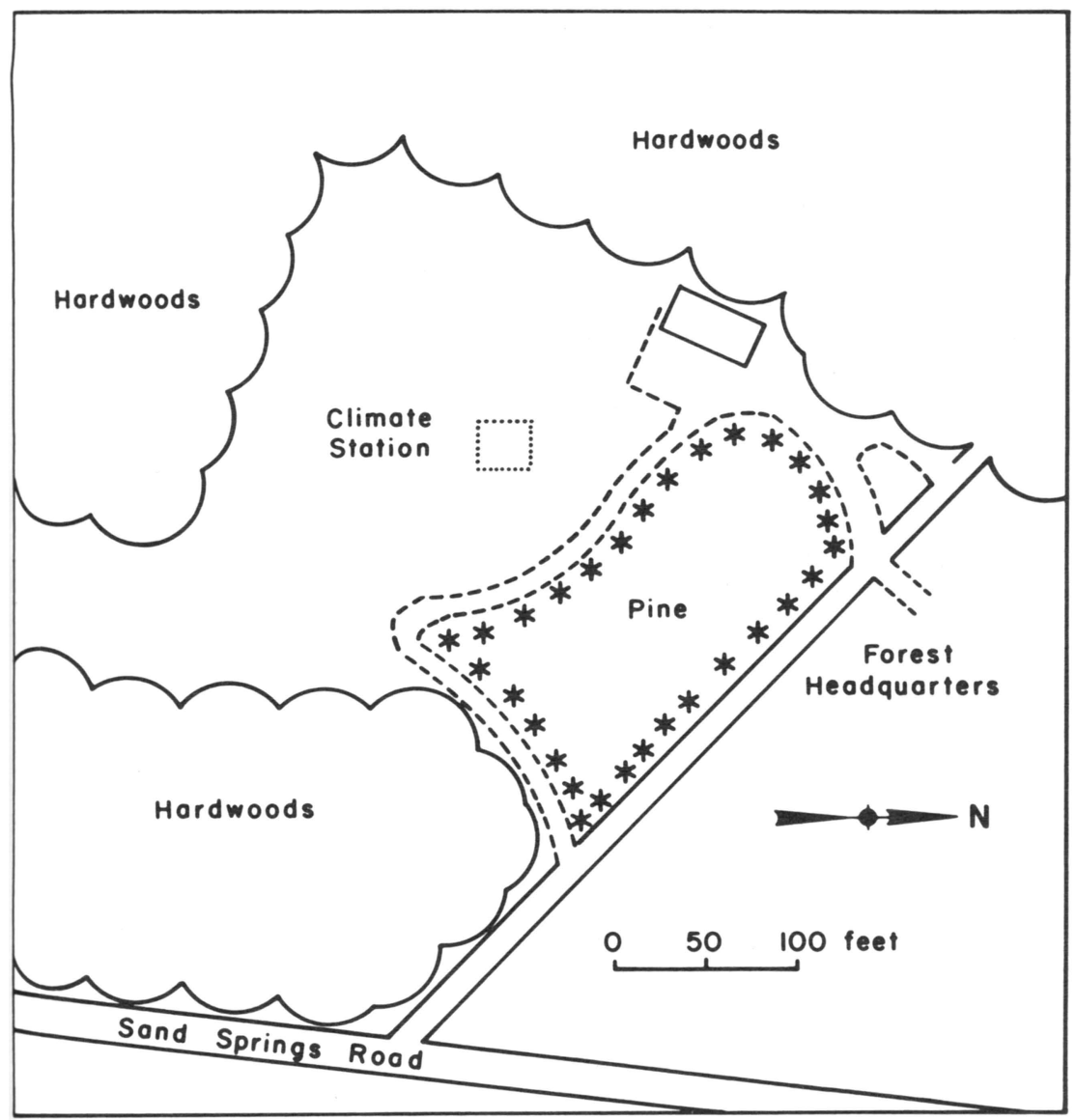

Figure 2. Diagrammatic view of the forest opening and the Climate Station.

Standard and recording rain gages were installed, and daily observations initiated on July 21, 1972. During November 1972, a five-foot anchor galvanized thain-link fence, $24 \times 24$ feet, was erected around the station, a climate shelter was installed, and snow depth measurements were initiated. Daily temperature observations (maximum-minimum) began on December 16, 1972. During May 1973 a hygrothermograph and an evaporation pan, with anemometer, were installed.

Figures 3 and 4 are diagrammatic and pictorial illustrations of the Station and nstrument placement. Figure 5 is a "globoscope" photograph of the Station as t appeared in October 1973. The globoscope technique (Lee, 1972) permits asy measurement of the vertical angles to local horizons (tree tops) in any irection. Periodic photographs of this type will be used to monitor changes in 
site exposure as the heights of the trees increase. In Figure 5, north is at the top of the photograph, and the vertical angles to the local horizon by directions are:

$\begin{array}{llll}\text { North } & 28.9^{\circ} & \text { South } & 17.3^{\circ} \\ \text { Northeast } & 25.4^{\circ} & \text { Southwest } 23.7^{\circ} \\ \text { East } & 16.3^{\circ} & \text { West } & 34.4^{\circ} \\ \text { Southeast } & 15.2^{\circ} & \text { Northwest } 27.1^{\circ}\end{array}$

Figure 5, coupled with the sun-path diagram (Figure 6), make it possible to determine the solar day length (i.e., the maximum number of hours of direct solar radiation) at the Station for any day of the year. For example, at the time of the summer solstice (22 June), the sun rises above the tree tops at 0650 hours

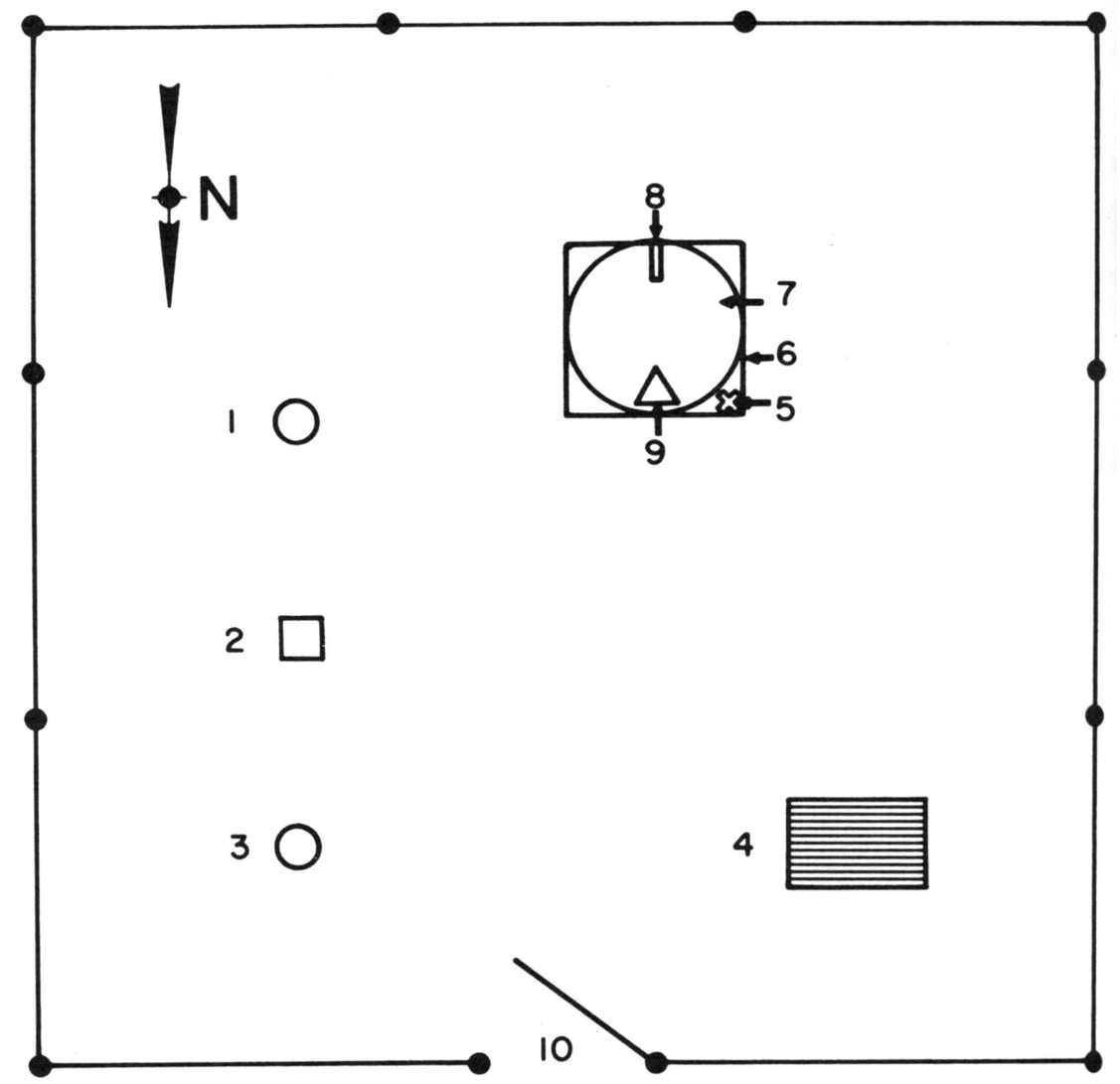

Figure 3. Diagrammatic view of the Climate Station and instrument placement (1: standard rain gage, 2: supplementary base, 3: recording rain gage, 4: shelter for maximum-minimum thermometers and hygrothermo. graph, 5: anemometer, 6: evaporation pan support, 7: evaporation pan, 8: Sixes thermometer, 9: stilling well, 10: gate). 


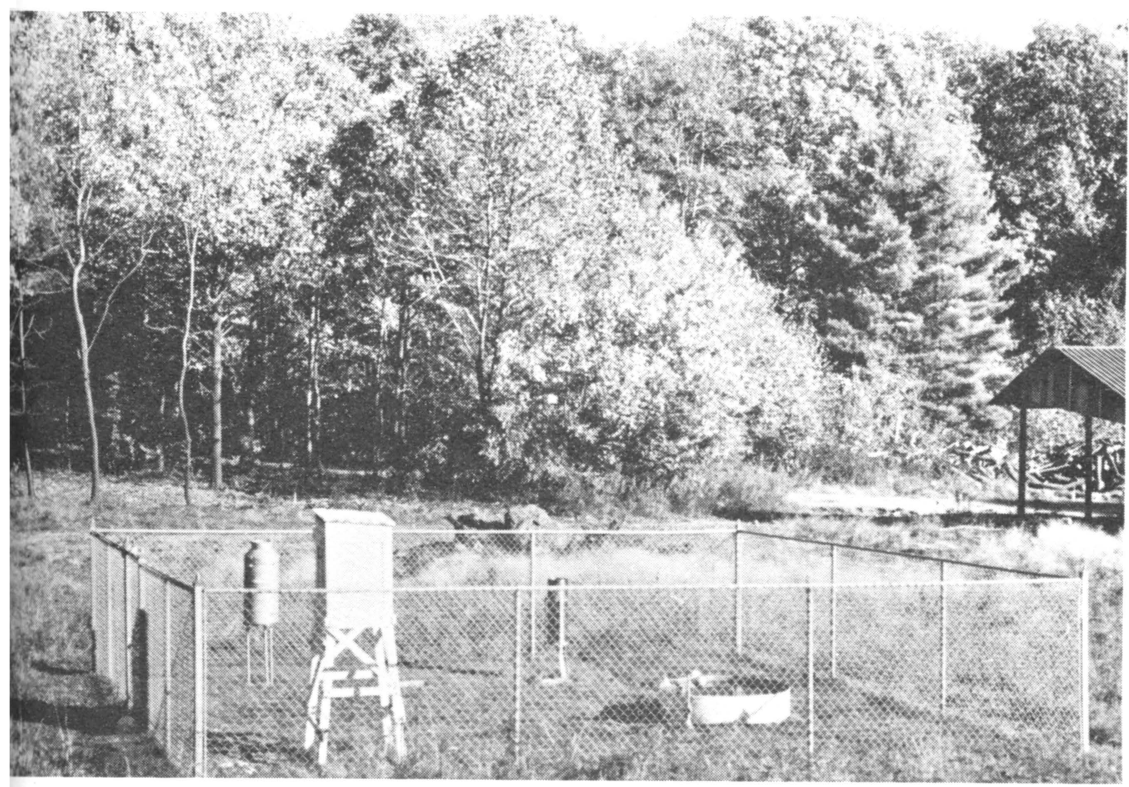

Figure 4. Coopers Rock Climate Station.

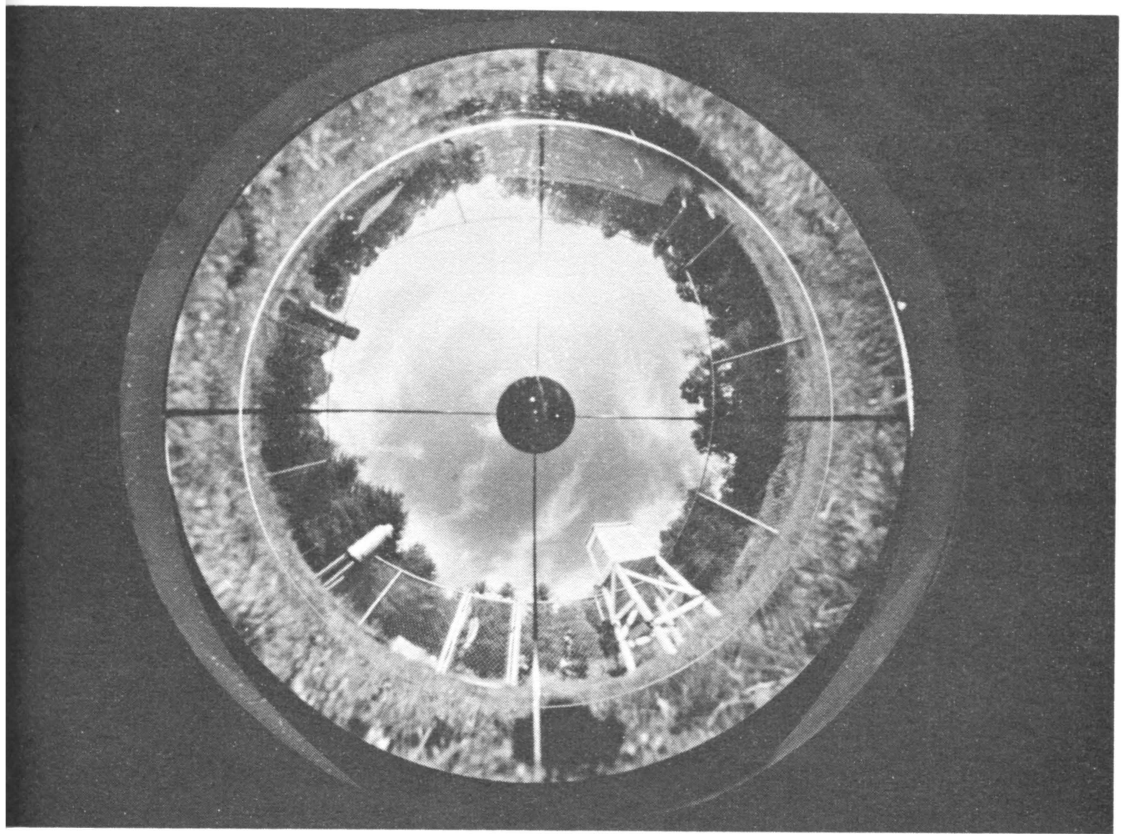

igure 5. Globoscope photograph of the Forest Climate Station. 
(solar time) and sets at 1615 hours, so the solar day length is 9 hours and 25 minutes. For selected dates of the year:

\begin{tabular}{llrrrrr}
\hline \hline \multicolumn{1}{c}{ Date } & $\begin{array}{c}\text { Rise } \\
\text { (hour) }\end{array}$ & $\begin{array}{c}\text { Set } \\
\text { (hour) }\end{array}$ & \multicolumn{2}{c}{$\begin{array}{c}\text { Day } \\
\text { (hrs) }\end{array}$} & $\begin{array}{r}\text { length } \\
\text { (min) }\end{array}$ \\
\hline & & & & & 9 & 25 \\
$6 / 22$ & & 0650 & 1615 & 9 & 25 \\
$5 / 21$ & $\& 7 / 24$ & 0645 & 1610 & 8 & 55 \\
$5 / 1$ & $\& 8 / 12$ & 0640 & 1535 & 9 & 0 \\
$4 / 16$ & $\& 8 / 28$ & 0640 & 1540 & 8 & 0 \\
$4 / 3$ & $\& 9 / 10$ & 0730 & 1530 & 7 & 50 \\
$3 / 21$ & $\& 9 / 23$ & 0725 & 1515 & 7 & 25 \\
$3 / 8$ & $\& 10 / 6$ & 0755 & 1520 & 7 & 0 \\
$2 / 23$ & $\& 10 / 20$ & 0800 & 1500 & 6 & 25 \\
$2 / 9$ & $\& 11 / 3$ & 0815 & 1440 & 5 & 30 \\
$1 / 21$ & $\& 11 / 22$ & 0850 & 1420 & 4 & 55 \\
$12 / 22$ & & 0905 & 1400 & & \\
\hline
\end{tabular}

These data show that the average solar day length at the Station is about 7 hours and 40 minutes, or about 64 per cent of the average 12-hour day for a completely exposed station.

\section{Observations}

An employee of the Division of Forestry, who resides at the Forest Headquarters, records observations every day of the year at 1800 hours local time. Alternate observers are available in emergencies, or when the resident observer is on official leave. J. L. Engle was the observer until June 1, 1973. Since then Stephen C. Hill has operated the Station.

The daily maximum and minimum temperatures, total precipitation, snowfall depth, evaporation, and wind data are tabulated each month. The monthly tabulations are reproduced and circulated to local researchers and interested faculty. At the end of each calendar year, an annual summary is prepared and circulated. The monthly and annual tabulations are cataloged and retained by the Forestry Library, and copies are mailed to the National Climatic Center in Asheville, North Carolina. The hygrothermograph and recording rain-gage charts are retained in the Division files.

\section{STATION COMPARISONS}

The Station data for the first two calendar years, 1973 and 1974, were compared with the simultaneous records for the stations at Brandonville and 


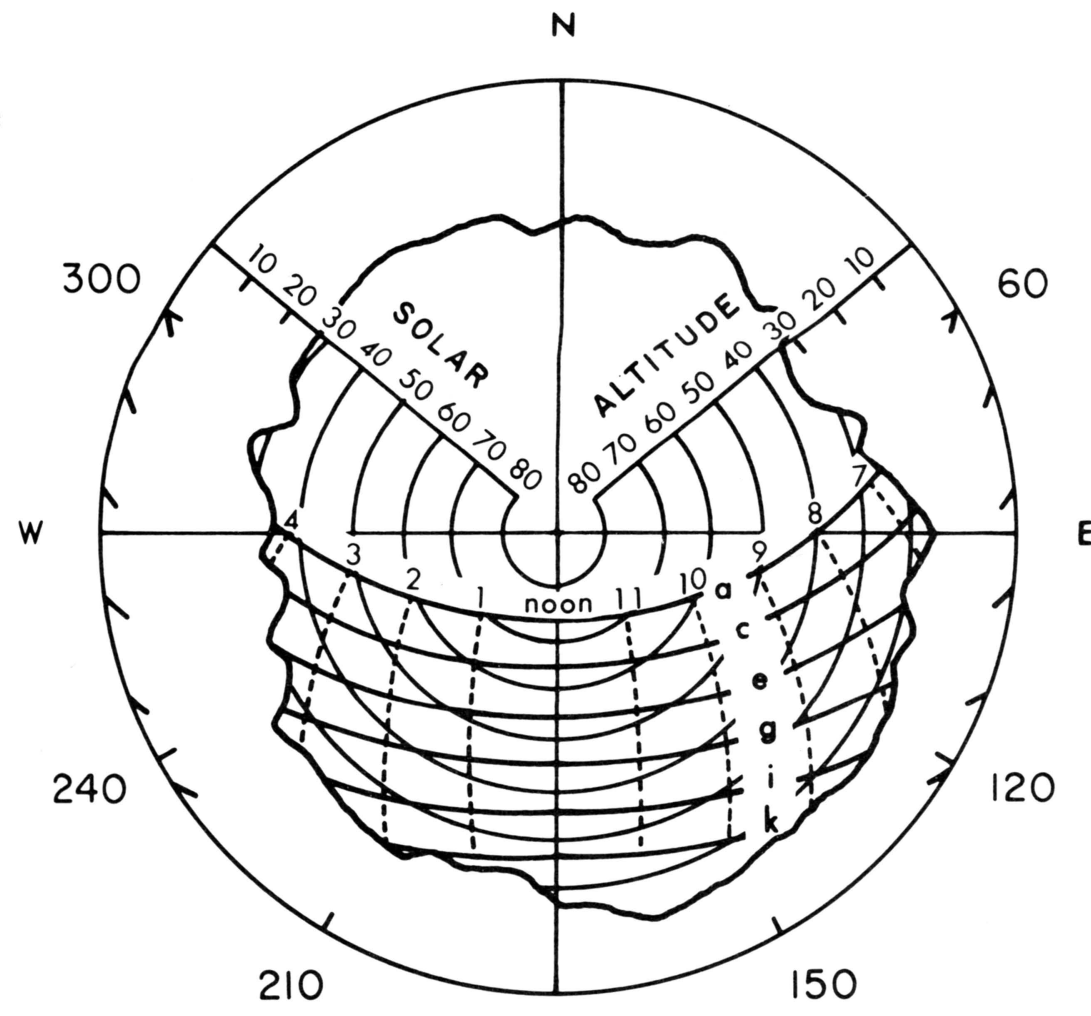

E

$S$

Figure 6. Sun path diagram for $40^{\circ}$ North Latitude showing the horizon line obtained from the globoscope photograph.

Morgantown. Only the precipitation and air temperature data were considered because wind, evaporation, and humidity were either not recorded at the stations outside the forest, or the data were not directly comparable. These dements of the Forest climate will be considered separately.

\section{Precipitation}

Monthly and annual totals of precipitation at the three stations, and the number of days per year with measurable precipitation, are given in Table 1. Total orecipitation at Morgantown was 75.2 per cent of the total at Coopers Rock; at Brandonville the total was $\mathbf{8 5 . 3}$ per cent of that in the Forest. These percentages re misleading, however, with respect to the seasonal trends.

Figures 7 and 8 show the monthly ratios of total precipitation at the outlying sations with that measured at Coopers Rock. There is a definite seasonal trend 


\section{TABLE 1. Monthly and Annual Precipitation Totals (Inches) at Morgantown (M), Brandonville (B), and Coopers Rock (CR)}

\begin{tabular}{lccccccc}
\hline \hline & \multicolumn{3}{c}{$\mathbf{1 9 7 3}$} & & & 1974 & \\
Month & M & B & CR & M & B & CR \\
\hline Jan. & 2.35 & 2.61 & 3.27 & & 5.20 & 6.54 & 7.08 \\
Feb. & 2.57 & 2.93 & 4.21 & 1.10 & 1.82 & 2.33 \\
Mar. & 2.43 & 2.18 & 3.51 & 2.79 & 3.99 & 4.85 \\
Apr. & 5.03 & 6.40 & 8.22 & 3.51 & 2.86 & 4.22 \\
May & 3.71 & 3.68 & 4.68 & 5.47 & 6.32 & 7.76 \\
June & 2.26 & 4.73 & 3.37 & 5.84 & 7.33 & 7.83 \\
July & 3.89 & 5.51 & 5.58 & 2.98 & 3.86 & 3.31 \\
Aug. & 5.36 & 4.29 & 4.64 & 4.41 & 4.23 & 4.18 \\
Sept. & 4.41 & 4.52 & 5.10 & 5.78 & 5.34 & 5.89 \\
Oct. & 2.76 & 3.18 & 3.60 & 1.27 & 1.39 & 1.78 \\
Nov. & 3.52 & 3.71 & 4.95 & 2.08 & 2.24 & 3.91 \\
Dec. & 5.38 & 5.11 & 6.84 & 4.18 & 5.36 & 6.26 \\
& & & & & & \\
Year & 43.67 & 48.85 & 57.97 & 44.61 & 15.28 & 59.40
\end{tabular}

Number of days with measurable precipitation

$\begin{array}{llllll}152 & 150 & 177 & 163 & 149 & 174\end{array}$

at both stations; the ratios tend to be much higher than average during the summer months, and lower than average during winter. Precipitation at both Morgantown and Brandonville exceeded Forest precipitation during one or more months each summer.

The average precipitation day produced 0.28 inches of water depth at Morgantown and 0.33 inches at Brandonville and Coopers Rock. The relative frequencies of precipitation amounts, for selected depth categories, are listed in Table 2. The percentages for the Forest Station are slightly greater than the others for precipitation depths exceeding 0.5 inches.

Total monthly and annual snowfall depths at Morgantown and Coopers Rock are listed in Table 3. Measurable snowfall occurred during six individual months each year at the Forest, and five months at Morgantown. The total two-year snowfall at Morgantown was only $\mathbf{3 8}$ per cent as great as that observed at the Forest.

During the two-year period, 1973-1974, precipitation at Coopers Rock was 8.62 inches per year greater than at Brandonville, and 14.55 inches greater than 


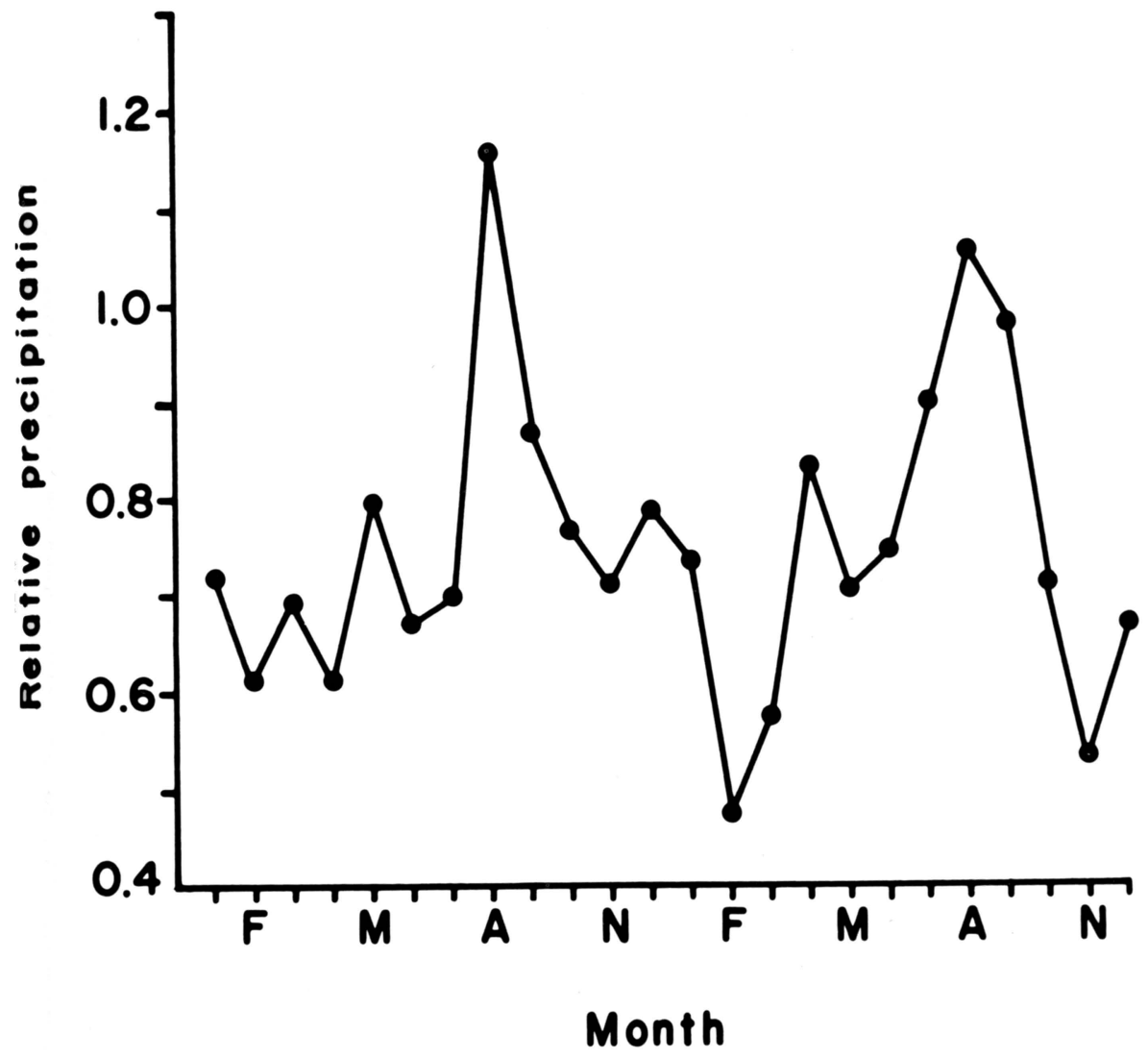

Figure 7. Monthly ratios of precipitation totals: Morgantown (M) versus Coopers Rock (CR), or M/CR.

TABLE 2. Relative Frequencies of Daily Precipitation Amounts (in per cent)

\begin{tabular}{lcccc}
\hline \hline Station & & \multicolumn{2}{c}{ Depth category, inches } \\
& $\mathbf{0 . 0 1 - 0 . 0 9}$ & $\mathbf{0 . 1 0 - 0 . 4 9}$ & $\mathbf{0 . 5 0 - 0 . 9 9}$ & $\mathbf{1 . 0 0}$ \\
\hline Morgantown & 37.7 & 44.9 & 12.3 & 5.1 \\
Brandonville & 26.4 & 52.1 & 15.1 & 6.4 \\
Coopers Rock & 37.3 & 38.2 & 17.7 & 6.8 \\
\hline
\end{tabular}




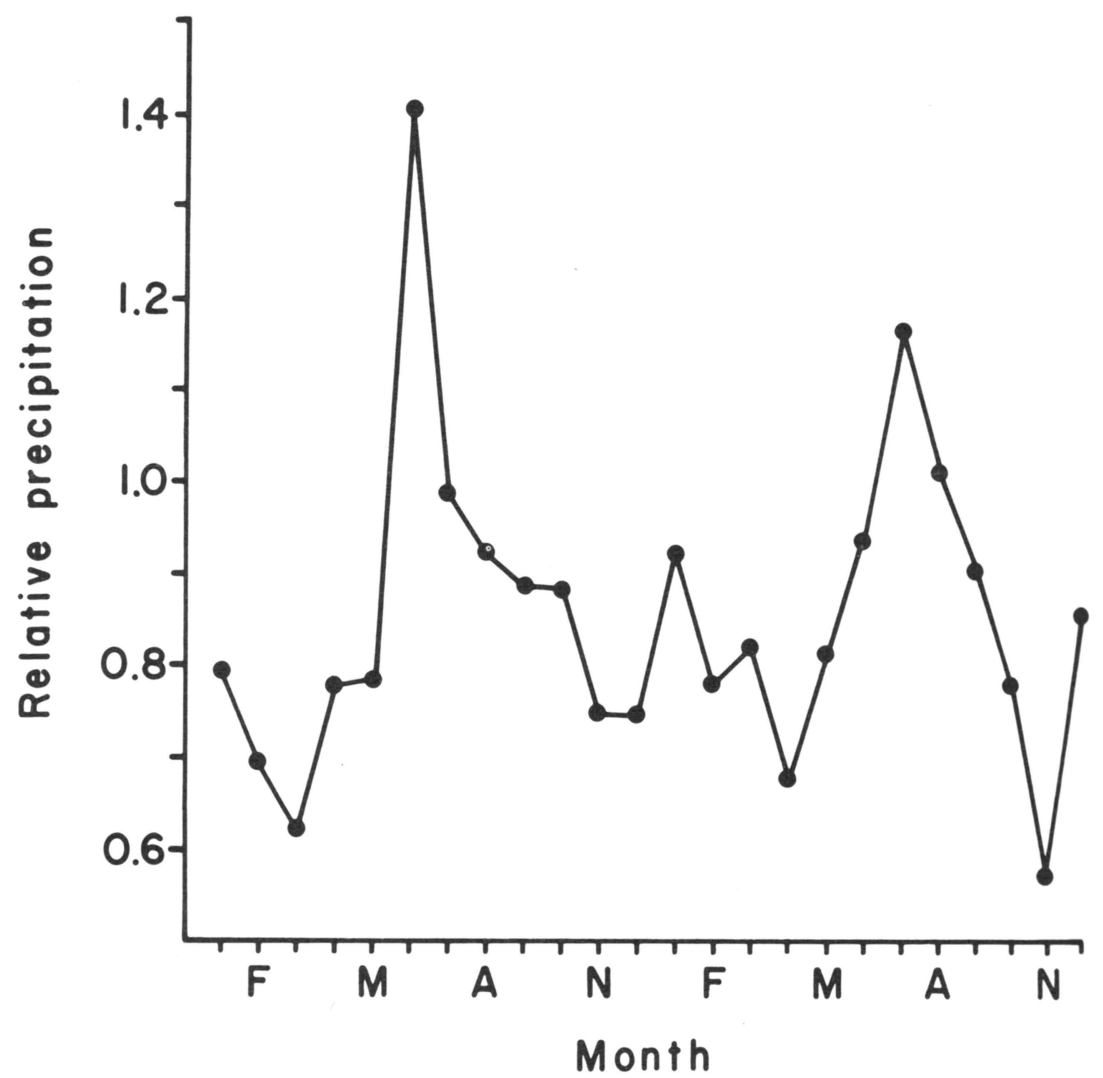

Figure 8. Monthly ratios of precipitation totals: Brandonville (B) versus Coopers Rock (CR), or B/CR.

TABLE 3. Monthly and Annual Snowfall Totals (in inches)

\section{Snowfall}

Year and station Nov. Dec. Jan. Feb. Mar. Apr. Total

1973

Morgantown

Coopers Rock

$\begin{array}{rrrrrrr}- & 21.0 & 5.5 & 4.0 & 3.6 & 3.4 & 37.5 \\ 4.5 & 30.6 & 10.7 & 18.6 & 6.4 & 7.8 & 78.6\end{array}$

1974

Morgantown

Coopers Rock

$\begin{array}{rrrrcrr}0.5 & 8.4 & 1.0 & 3.1 & - & 1.5 & 14.5 \\ 10.6 & 31.4 & 2.7 & 10.2 & 0.3 & 3.3 & 58.5\end{array}$


at Morgantown. These differences are far too great to be accounted for in terms of the elevation (orographic) effect in West Virginia (Grafton and Dickerson, 1969; and Chang, 1973). Chang and Lee (1975) showed that precipitation gaging errors (i.e., deficiencies in catch related to wind effects) frequently exceed 10 per cent for exposed stations. The stations at Morgantown and Brandonville are virtually unprotected, whereas the Forest Station is surrounded by trees (Figure 5).

In addition to gaging errors, the influences of local environment on precipitation are worthy of consideration. Whereas the effects of forest cover on gross precipitation are almost certainly negligible (Penman, 1963; Chang and Lee, 1974), evidence that city development can increase local precipitation has been accumulating (Geiger, 1965; Landsberg, 1968). Intense surface heating, which can trigger local convective showers in summer, is greater in non-forested and metropolitan areas. This is a possible explanation of the relatively high precipitation at Brandonville and Morgantown during the warmer months (Figures 7 and 8).

\section{Air Temperature}

The air temperature data obtained from maximum and minimum thermometer records were analyzed to determine characteristic differences among the stations. Both elevation and local environmental influences were to be expected. For purposes of comparison, the thermal climates of the stations can be classified as: Morgantown, Urban non-forest; Brandonville, Rural non-forest; and Coopers Rock, Rural forest.

The Forest Station is at an elevation 1,030 feet higher than Morgantown, and 477 feet higher than Brandonville.

Within a relatively restricted climatic zone, e.g., the humid northeastern United States, it has been shown that mean air temperature is largely a function of latitude and elevations (Lee, 1969). The decrease of mean temperature with devation varies from month to month from about 2.3 to $3.3^{\circ} \mathrm{F}$ per thousand feet (annual mean $2.9^{\circ} \mathrm{F}$ ). Other influences, for example, local land form, forest cover, cultural developments, and large water bodies, can affect local temperatures markedly. City and forest climates are generally warmer than surrounding reas; temperatures in small forest openings usually are intermediate between those in forested and open environments.

The mean monthly and annual air temperatures at the stations for 1973-1974 are listed in Table 4, along with the corresponding maxima and minima. Based on the annual average, the Forest Station was $2.3^{\circ} \mathrm{F}$ cooler, and $0.1^{\circ} \mathrm{F}$ warmer than the stations at Morgantown and Brandonville, respectively. Monthly differences in the temperature means are illustrated in Figure 9. During late ummer, air temperature at the Forest Station was more than $4^{\circ} \mathrm{F}$ cooler than it Morgantown, but in January and February it was slightly warmer. At Brandonville, the means were slightly higher in summer, and slightly lower in winter, than at Coopers Rock.

It is apparent from these comparisons with both non-forest stations that nean air temperature at the Forest is higher than expected during the winter, 
TABLE 4. Air temperatures $\left({ }^{\circ} \mathrm{F}\right)$ at Morgantown (M), Brandonville (B), and Coopers Rock (CR), 1973-1974

\begin{tabular}{|c|c|c|c|c|c|c|c|c|c|}
\hline \multirow{2}{*}{ Month } & \multicolumn{3}{|c|}{ Mean } & \multicolumn{3}{|c|}{ Average maximum } & \multicolumn{3}{|c|}{ Average minimum } \\
\hline & (M) & (B) & (CR) & (M) & & (CR) & (M) & (B) & (CR) \\
\hline Jan. & 32.4 & 32.2 & 33.0 & 40.8 & 41.7 & 41.6 & 24.0 & 22.6 & 24.4 \\
\hline Feb. & 29.0 & 28.2 & 29.2 & 37.9 & 38.3 & 38.7 & 20.1 & 18.2 & 19.8 \\
\hline Mar. & 45.5 & 43.4 & 44.3 & 55.6 & 54.6 & 54.8 & 35.4 & 32.3 & 33.8 \\
\hline Apr. & 50.7 & 47.5 & 49.3 & 60.7 & 58.4 & 60.2 & 40.7 & 36.6 & 38.4 \\
\hline May & 58.2 & 55.8 & 56.1 & 68.2 & 66.3 & 66.9 & 48.3 & 45.2 & 45.3 \\
\hline June & 67.9 & 65.2 & 64.7 & 78.1 & 76.6 & 74.8 & 57.7 & 53.7 & 54.6 \\
\hline July & 71.4 & 68.4 & 68.3 & 81.9 & 80.2 & 78.1 & 60.8 & 56.6 & 58.3 \\
\hline Aug. & 71.7 & 68.4 & 67.5 & 80.8 & 79.5 & 76.5 & 62.5 & 57.3 & 58.5 \\
\hline Sept. & 64.3 & 61.0 & 59.9 & 74.5 & 72.7 & 69.1 & 54.0 & 49.2 & 50.6 \\
\hline Oct. & 53.3 & 50.4 & 50.6 & 64.1 & 62.9 & 60.4 & 42.4 & 37.9 & 40.9 \\
\hline Nov. & 43.9 & 41.4 & 40.8 & 52.9 & 51.5 & 49.7 & 34.8 & 31.3 & 32.0 \\
\hline Dec. & 34.2 & 31.7 & 31.1 & 41.0 & 39.4 & 38.3 & 27.8 & 23.9 & 23.8 \\
\hline Year & 51.9 & 49.5 & 49.6 & 61.4 & 60.2 & 59.1 & 42.4 & 38.7 & 40.0 \\
\hline
\end{tabular}

and lower than expected during summer. This is the typical forest influence; its magnitude for the forest opening can be inferred from the data. For example, based on an earlier study (Lee, 1969) it is known that average temperature decreases per 1,000 feet of elevation are $2.84^{\circ} \mathrm{F}$ in February, and $3.18^{\circ} \mathrm{F}$ in August. Using these coefficients and the known elevation difference (Coopers Rock-Morgantown, i.e., 1,030 feet), the inferred influences are $3.1^{\circ} \mathrm{F}$ (February) and $-0.9^{\circ} \mathrm{F}$ (August).

Monthly differences in the average temperature maxima and minima are illustrated in Figures 10 and 11. The average differences in maxima vary from -0.8 to $5.4^{\circ} \mathrm{F}$ for Morgantown versus Coopers Rock, and from -1.8 to $3.6^{\circ} \mathrm{F}$ for Brandonville. The seasonal variation is pronounced. The corresponding differences in minimum air temperatures range from -0.4 to $4.0^{\circ} \mathrm{F}$ (Morgantown), and from -3.0 to $0.1^{\circ} \mathrm{F}$ (Brandonville).

The highest maximum and lowest minimum air temperatures recorded at the three stations each month are listed in Table 5 . The maxima were almost invariably higher at the non-forest stations, and the minima were almost invariably lowest at Brandonville. The monthly differences (non-forest stations versus Coopers Rock) are illustrated in Figures 12 and 13.

The mean temperatures, and the average and extreme maxima and minima, do not adequately describe characteristic differences in the thermal regimes among the stations. The frequencies, ranges, and interdiurnal changes ir temperature help to identify and clarify significant dissimilarities. For example 
Table 6 lists the number of days per year during which given levels of temperature were observed. The higher maximum temperatures occurred much more frequently at the non-forest stations. Sub-freezing temperatures were generally more frequent at the higher elevations, especially at Brandonville.

The absolute two-year temperature ranges (i.e., highest maximum minus lowest minimum) for the stations were: Morgantown, $104^{\circ} \mathrm{F}$; Brandonville, $102^{\circ} \mathrm{F}$; and Coopers Rock, $95^{\circ} \mathrm{F}$. The monthly and daily ranges and interdiurnal changes are listed in Table 7. The monthly range of temperature was distinctly much greater during colder months at all stations. Figure 14 shows that, as a rule, the monthly ranges were greater at stations outside the Forest.

Maximum diurnal temperature ranges were generally greatest during spring (Morgantown and Coopers Rock) or autumn (Brandonville). Figure 15 shows that these ranges were smallest at the Forest Station except during the spring

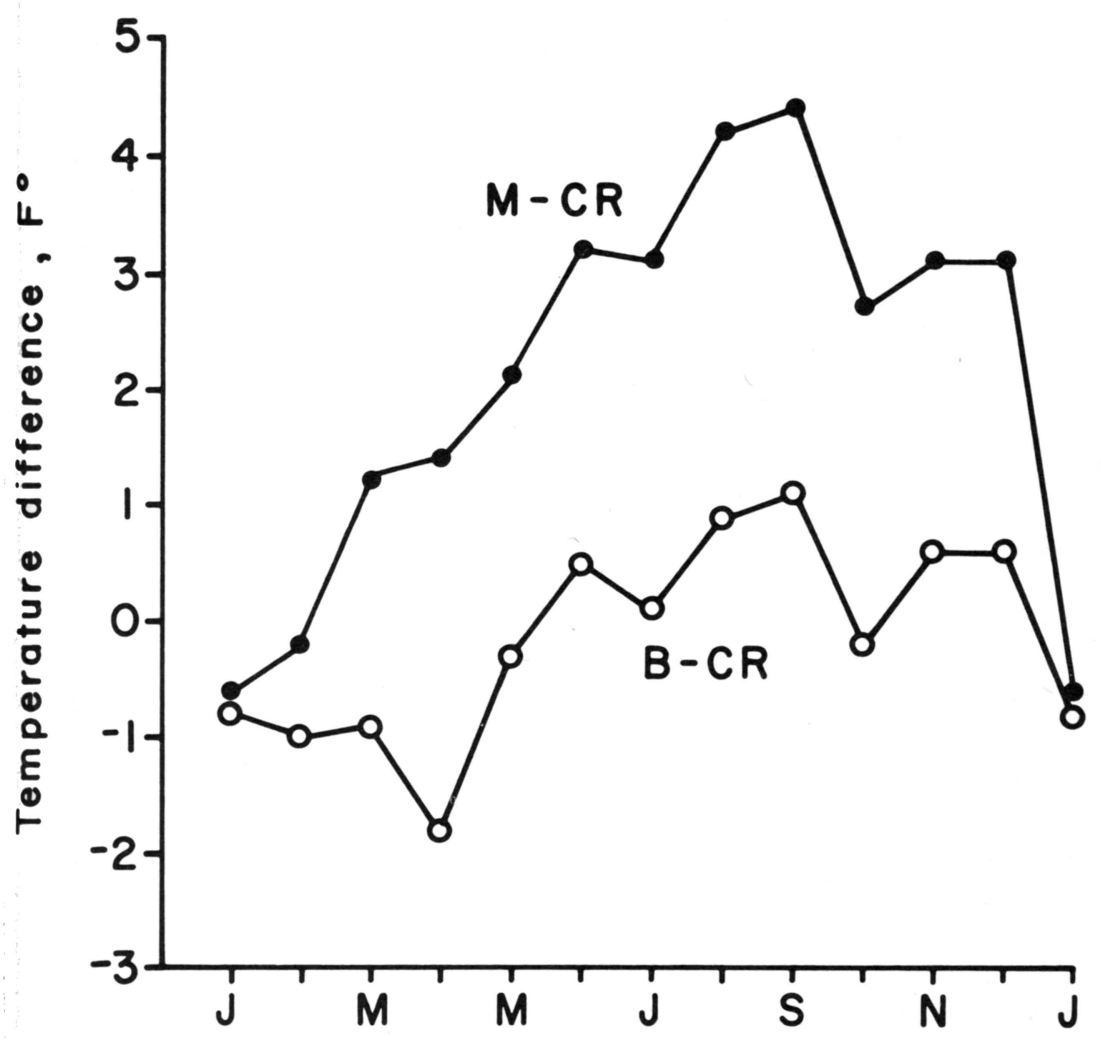

Month

Figure 9. Monthly differences in mean air temperatures at Morgantown (M) and Brandonville (B) versus Coopers Rock (CR). 


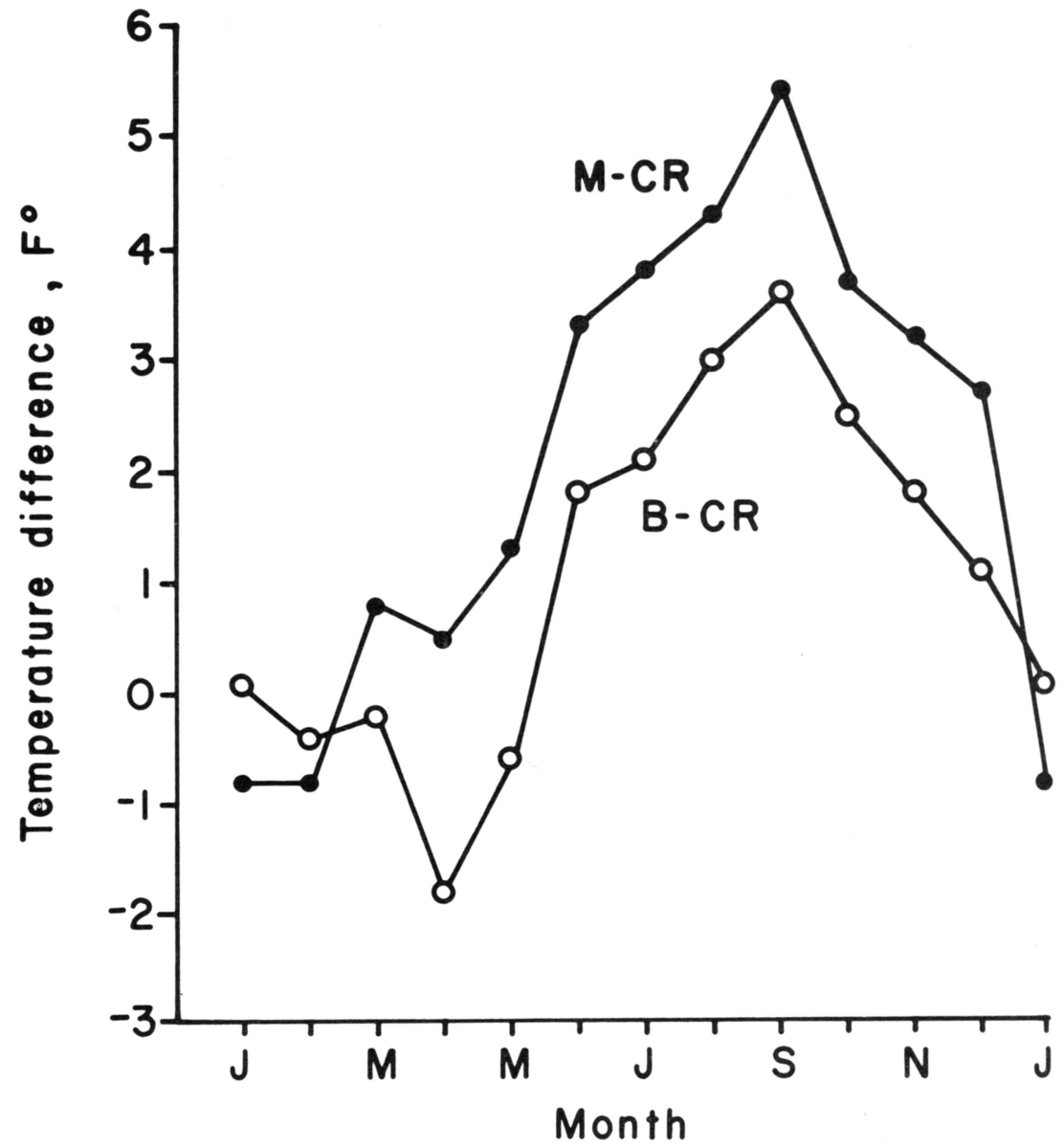

Figure 10. Monthly differences in average air temperature maxima at Morgantown (M) and Brandonville (B) versus Coopers Rock (CR).

(March-June). The average diurnal ranges (Figure 16) peaked in early autumn (October) at the non-forest stations, and in spring (April) at Coopers Rock; they were lowest at the Forest Station from June through November, and at Morgantown the remainder of the year. In contrast to the monthly ranges, the average diurnal ranges were generally lowest during the coldest months.

The average day-to-day changes in mean air temperature (Figure 17) were highly correlated with the monthly ranges (Figure 14), and inversely with monthly means (i.e., highest during the coldest month, February, and lowest during the warmest month, August). The mean interdiurnal changes were generally smallest at Coopers Rock, and greatest at Brandonville. This is yet another indication of the moderating influence of forest cover on local climate. 


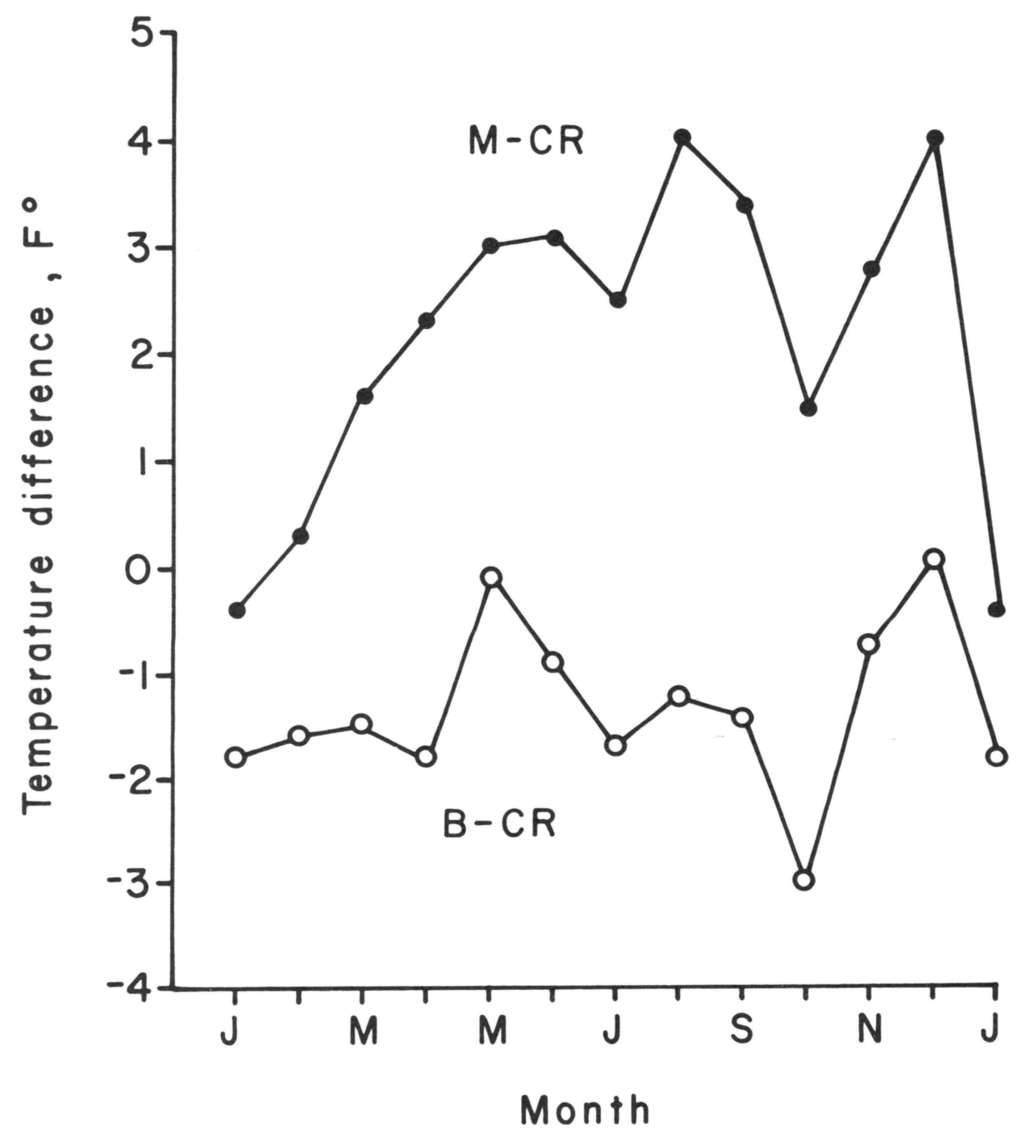

Figure 11. Monthly differences in average air temperature minima at Morgantown (M) and Brandonville (B) versus Coopers Rock (CR).

The length of the freeze-free season (i.e., the greatest number of consecutive days during which air temperature is always greater than $32^{\circ} \mathrm{F}$ ) is a measure of the local growing season:

Station

1973

1974

Morgantown

Days Freeze-free

Brandonville 
In spite of the elevation differences, it is notable that the freeze-free period was consistently greater at Coopers Rock than at Brandonville, and equal to or slightly less than the season at Morgantown.

\section{ADDITIONAL FOREST CLIMATE DATA}

\section{Evaporation and Wind}

Daily evaporation and wind measurements were initiated in June 1973, and were continued throughout most of the freeze-free seasons during 1973-1974. No attempt was made to correlate evaporation data with atmospheric parameters. Pan water temperature measurements were initiated during the summer of 1974. The mean and maximum values of wind speed and pan evaporation are listed in Table 8.

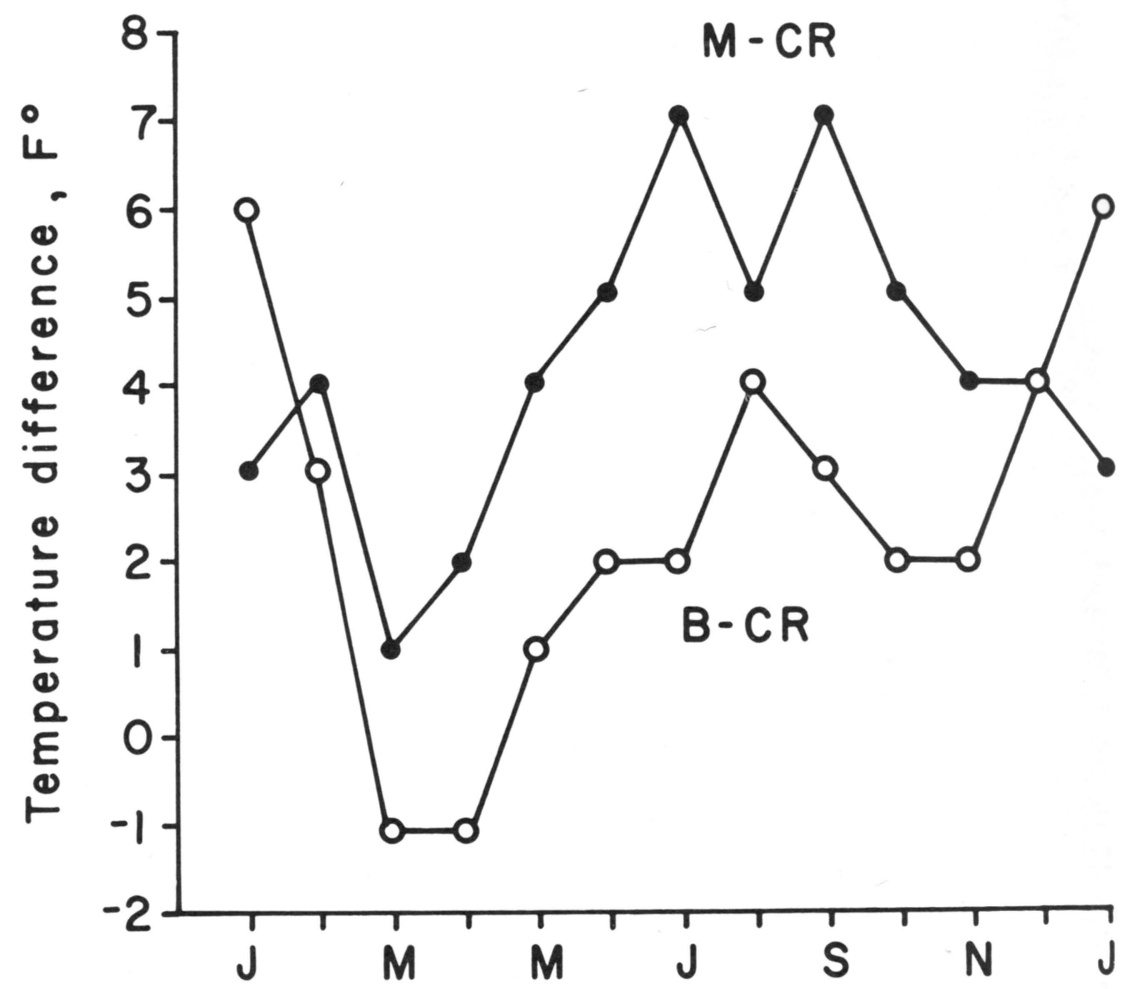

\section{Month}

Figure 12. Monthly differences in highest air temperature maxima at Morgantown (M) and Brandonville (B) versus Coopers Rock (CR). 


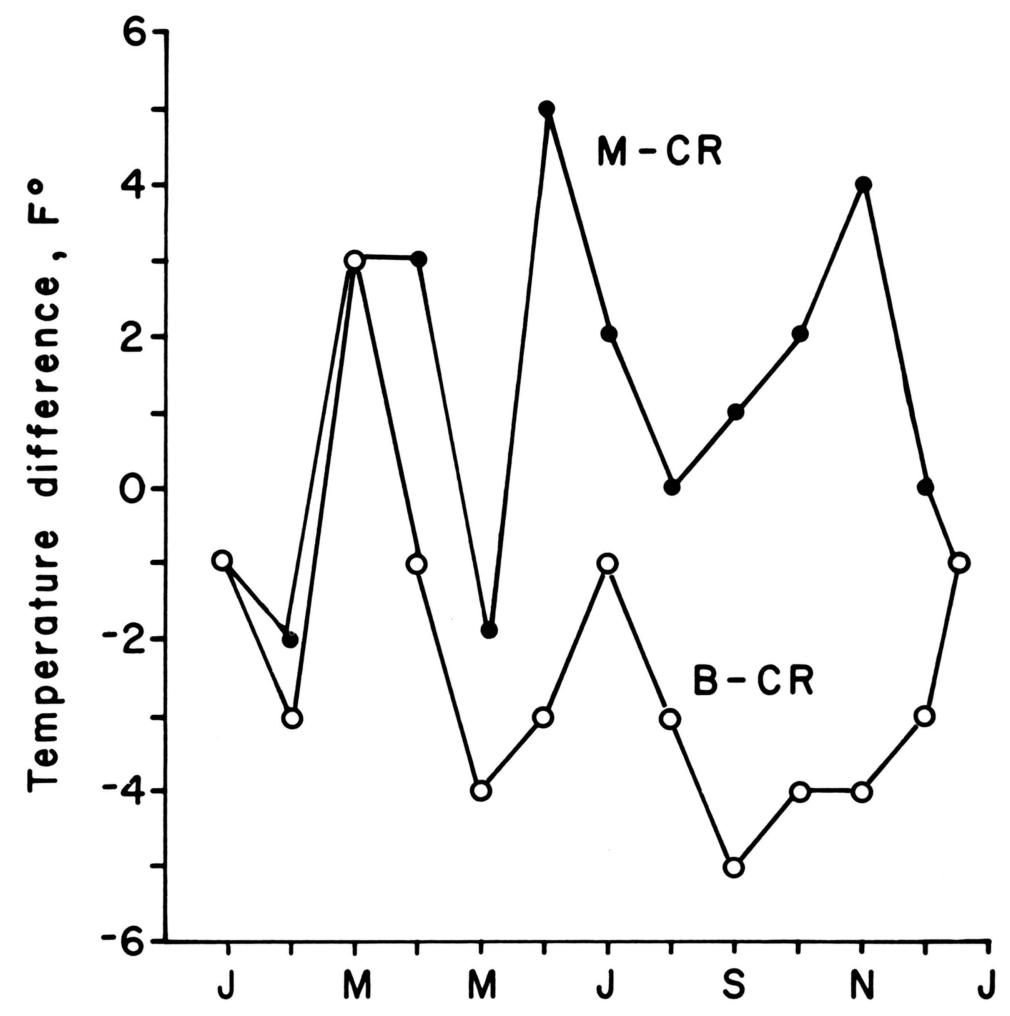

\section{Month}

Figure 13. Monthly differences in lowest air temperature minima at Morgantown (M) and Brandonville (B) versus Coopers Rock (CR).

\section{Humidity}

The hygrothermograph charts for July 1973-1974, and January 1974-1975, were analyzed to obtain characteristic humidity data for the Forest Station. The highest and lowest values of relative humidity each day, and simultaneous air temperatures, were used to calculate ambient vapor pressures. The mean values and standard deviations are listed in Table 9.

The average diurnal range of relative humidity was 27.1 per cent in January and 49.4 per cent in July. Ambient vapor pressure is relatively constant diurnally, in the absence of air mass changes, so that relative humidity is largely a function of air temperature. This means that the higher daytime relative humidities that are typical of forested areas are primarily the result of reduced temperatures. 
TABLE 5. Extreme Air Temperatures $\left({ }^{\circ} \mathrm{F}\right)$ at Morgantown (M), Brandonville (B), and Coopers Rock (CR), 1973-1974

\begin{tabular}{|c|c|c|c|c|c|c|}
\hline \multirow{2}{*}{$\begin{array}{l}\text { Month } \\
\text { Jan. }\end{array}$} & \multicolumn{3}{|c|}{$\begin{array}{l}\text { Highest maximum } \\
\text { (M) (B) (CR) }\end{array}$} & \multicolumn{3}{|c|}{$\begin{array}{l}\text { Lowest minimum } \\
\text { (M) (B) (CR) }\end{array}$} \\
\hline & 67 & 70 & 64 & 0 & 0 & 1 \\
\hline Feb. & 62 & 61 & 58 & -10 & -11 & -8 \\
\hline Mar. & 80 & 78 & 79 & 10 & 10 & 7 \\
\hline Apr. & 84 & 81 & 82 & 19 & 15 & 16 \\
\hline May & 90 & 87 & 86 & 27 & 25 & 29 \\
\hline June & 89 & 86 & 84 & 44 & 36 & 39 \\
\hline July & 92 & 87 & 85 & 46 & 43 & 44 \\
\hline Aug. & 92 & 91 & 87 & 44 & 41 & 44 \\
\hline Sept. & 94 & 90 & 87 & 32 & 26 & 31 \\
\hline Oct. & 80 & 77 & 75 & 26 & 20 & 24 \\
\hline Nov. & 77 & 75 & 73 & 16 & 8 & 12 \\
\hline Dec. & 65 & 65 & 61 & 5 & 2 & 5 \\
\hline Year & 94 & 91 & 87 & -10 & -11 & -8 \\
\hline
\end{tabular}

TABLE 6. Temperature Frequencies (Days per Year) for Various Ranges of Maxima and Minima

\begin{tabular}{cccc}
\hline \hline Temperature, ${ }^{{ }^{\circ}} \mathbf{F}$ & Morgantown & Brandonville & Coopers Rock \\
\hline Maximum & & & \\
$\geq 90$ & 5 & 2 & 0 \\
85 & 30 & 17 & 6 \\
80 & 71 & 56 & 35 \\
75 & 112 & 103 & 79 \\
& & & \\
Minimum & & & 118 \\
$\leq 32$ & 114 & 140 & 41 \\
20 & 33 & 45 & 13 \\
10 & 12 & 13 & 1 \\
0 & 2 & 2 & \\
\hline
\end{tabular}


TABLE 7. Monthly and Diurnal Temperature Ranges, and Interdiurnal Temperature Changes $\left(\mathrm{F}^{\mathrm{O}}\right)$ at Morgantown (M), Brandonville (B), and Coopers Rock (CR), 1973-1974

\begin{tabular}{|c|c|c|c|c|c|c|c|c|c|c|c|c|}
\hline \multirow{3}{*}{ Month } & \multicolumn{9}{|c|}{ Range } & \multirow{2}{*}{\multicolumn{3}{|c|}{$\begin{array}{l}\text { Mean interdiurnal } \\
\text { Change }\end{array}$}} \\
\hline & \multicolumn{3}{|c|}{ Monthly } & \multicolumn{3}{|c|}{ Maximum diurnal } & \multicolumn{3}{|c|}{ Mean diurnal } & & & \\
\hline & (M) & (B) & (CR) & (M) & (B) & (CR) & (M) & (B) & (CR) & (M) & (B) & (CR) \\
\hline Jan. & 62 & 70 & 63 & 37 & 36 & 33 & 16.8 & 19.1 & 17.2 & 7.0 & 7.2 & 7.3 \\
\hline Feb. & 68 & 72 & 66 & 39 & 38 & 35 & 17.8 & 20.1 & 18.9 & 8.1 & 8.2 & 7.4 \\
\hline Mar. & 66 & 65 & 67 & 43 & 37 & 39 & 20.2 & 22.3 & 21.0 & 6.1 & 6.5 & 5.8 \\
\hline Apr. & 62 & 65 & 65 & 50 & 40 & 42 & 19.9 & 21.8 & 21.8 & 6.1 & 7.5 & 6.5 \\
\hline May & 63 & 62 & 57 & 43 & 34 & 45 & 19.9 & 21.1 & 21.5 & 4.2 & 6.4 & 4.4 \\
\hline June & 45 & 49 & 43 & 31 & 32 & 31 & 20.3 & 22.9 & 20.1 & 3.3 & 4.2 & 3.1 \\
\hline July & 46 & 44 & 41 & 32 & 32 & 30 & 21.1 & 23.6 & 19.8 & 3.4 & 4.0 & 2.8 \\
\hline Aug. & 48 & 50 & 43 & 29 & 33 & 28 & 18.3 & 22.2 & 18.0 & 2.4 & 3.0 & 1.9 \\
\hline Sept. & 54 & 56 & 51 & 35 & 36 & 30 & 20.4 & 23.4 & 18.5 & 3.9 & 4.7 & 3.7 \\
\hline Oct. & 53 & 57 & 51 & 38 & 41 & 32 & 21.7 & 25.0 & 19.5 & 5.3 & 4.9 & 4.9 \\
\hline Nov. & 61 & 67 & 61 & 37 & 40 & 35 & 18.1 & 20.2 & 17.7 & 7.3 & 7.3 & 6.8 \\
\hline Dec. & 60 & 56 & 56 & 35 & 31 & 31 & 13.6 & 15.5 & 14.4 & 6.9 & 6.0 & 5.8 \\
\hline Year & 104 & 102 & 95 & 50 & 41 & 45 & 19.0 & 21.5 & 19.1 & 5.3 & 5.8 & 5.0 \\
\hline
\end{tabular}

Figure 18 shows the accumulated frequencies of ambient vapor pressure (e) during January and July. The values range from about 1 to $12 \mathrm{mb}$ in January and from about 9 to $23 \mathrm{mb}$ in July. The median value for January $(4.19 \mathrm{mb})$ is slightly lower than the mean $(4.71 \mathrm{mb})$; the median for July $(16.58 \mathrm{mb})$ is slightly higher than the mean $(15.95 \mathrm{mb})$.

Ambient vapor pressure (e) defines the limits within which evaporation, sublimation, and condensation processes can occur in terms of surface temperature. Water vapor moves in the direction of decreasing vapor pressure, and the saturation vapor pressure $\left(\mathrm{e}_{\mathrm{s}}\right)$ at an evaporating surface is strictly a function of surface temperature (Table 10). The rate of evaporation, sublimation, and condensation is proportional to the vapor pressure difference $\left(\mathrm{e}_{\mathrm{s}}-\mathrm{e}\right)$.

On an average July day, $\mathrm{e}=16.0 \mathrm{mb}$, the vapor pressure difference, $\mathrm{e}_{\mathrm{s}} \mathrm{e}^{-\mathrm{e}}$, for a surface temperature of $75^{\circ} \mathrm{F}$, would be 29.7-16.0 $=13.7 \mathrm{mb}$, and evaporation or transpiration could occur at a relatively rapid rate. But the evaporation rate from a forest stream would be small (or negative), depending on the water temperature. Forest stream temperatures in West Virginia range between about 55 and $60^{\circ} \mathrm{F}$ in summer. At $55^{\circ} \mathrm{F}, \mathrm{e}_{\mathrm{s}}-\mathrm{e}=-1.2 \mathrm{mb}$, and negative evaporation (condensation) must occur. At $60^{\circ} \mathrm{F}, \mathrm{e}_{\mathrm{s}}^{-\mathrm{e}}=1.7 \mathrm{mb}$, and some evaporation could occur。 
$\longrightarrow$ Coopers Rock

------ Morgantown

-............. Brandonville

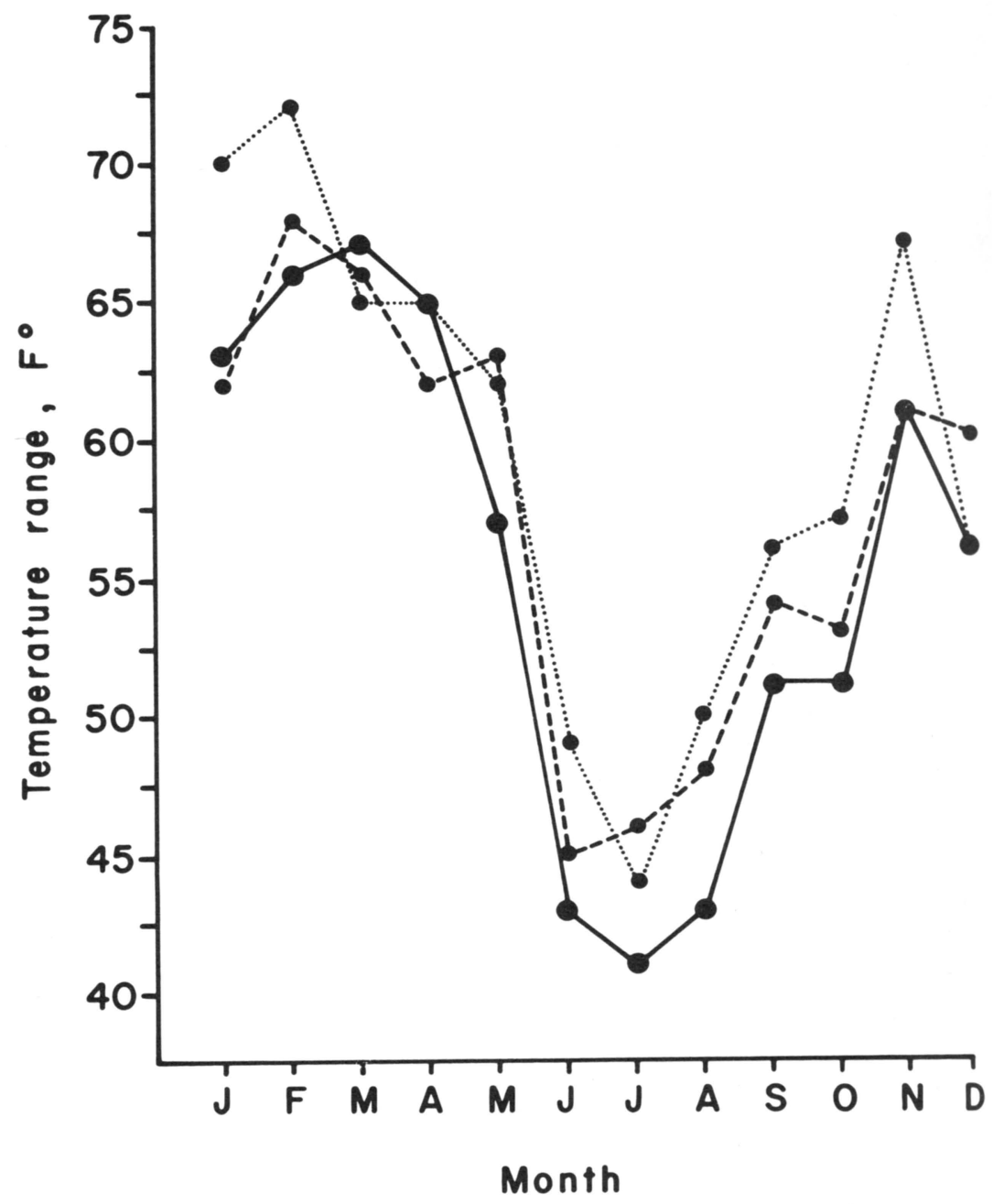

Figure 14. Extreme monthly ranges of air temperature at Morgantown, Brandonville, and Coopers Rock. 
$\longrightarrow$ Coopers Rock

$\bullet---\infty$ Morgantown

-.......... Brandonville

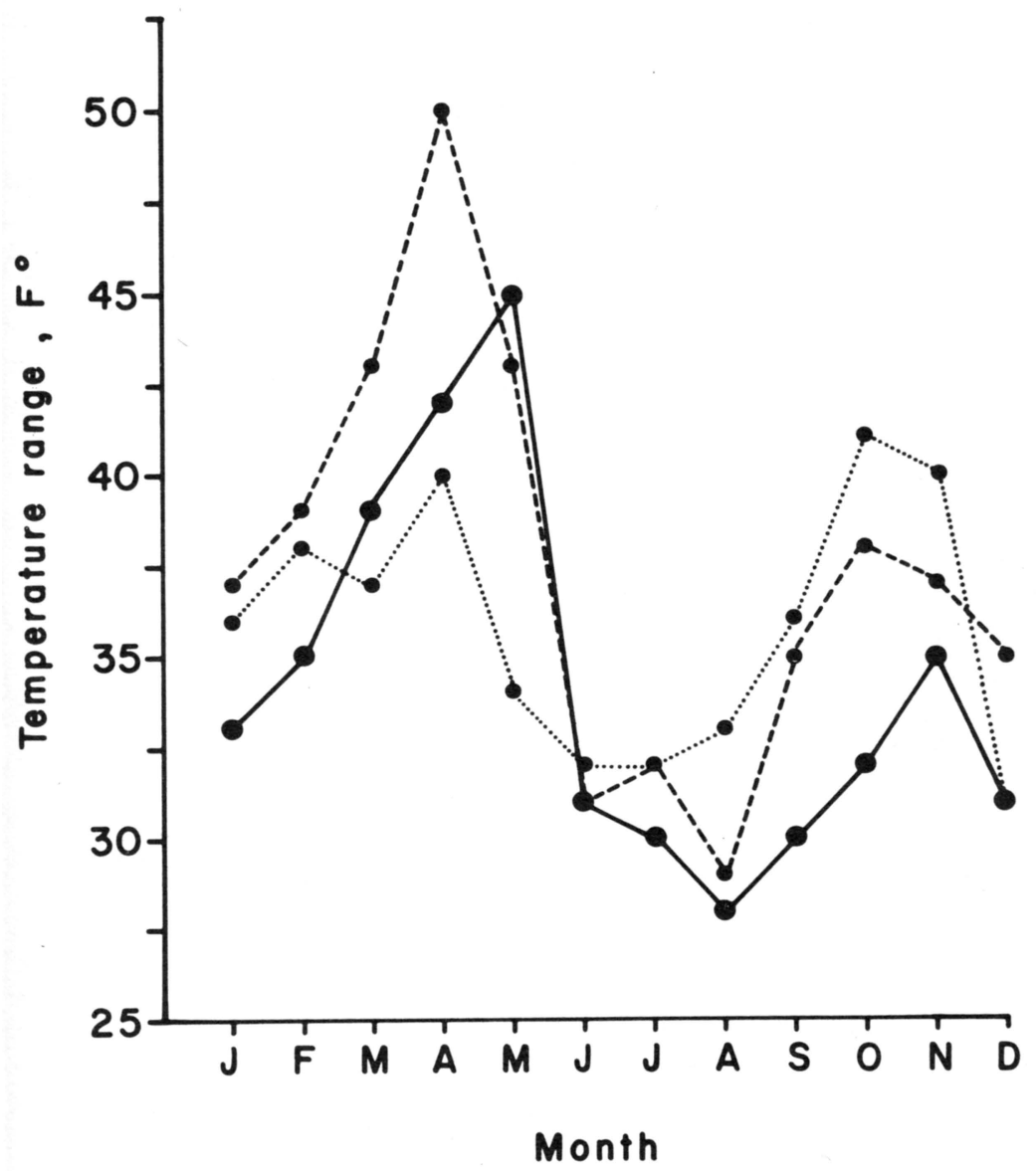

igure 15. Maximum diurnal ranges of air temperature by months at Morgantown, Brandonville, and Coopers Rock. 


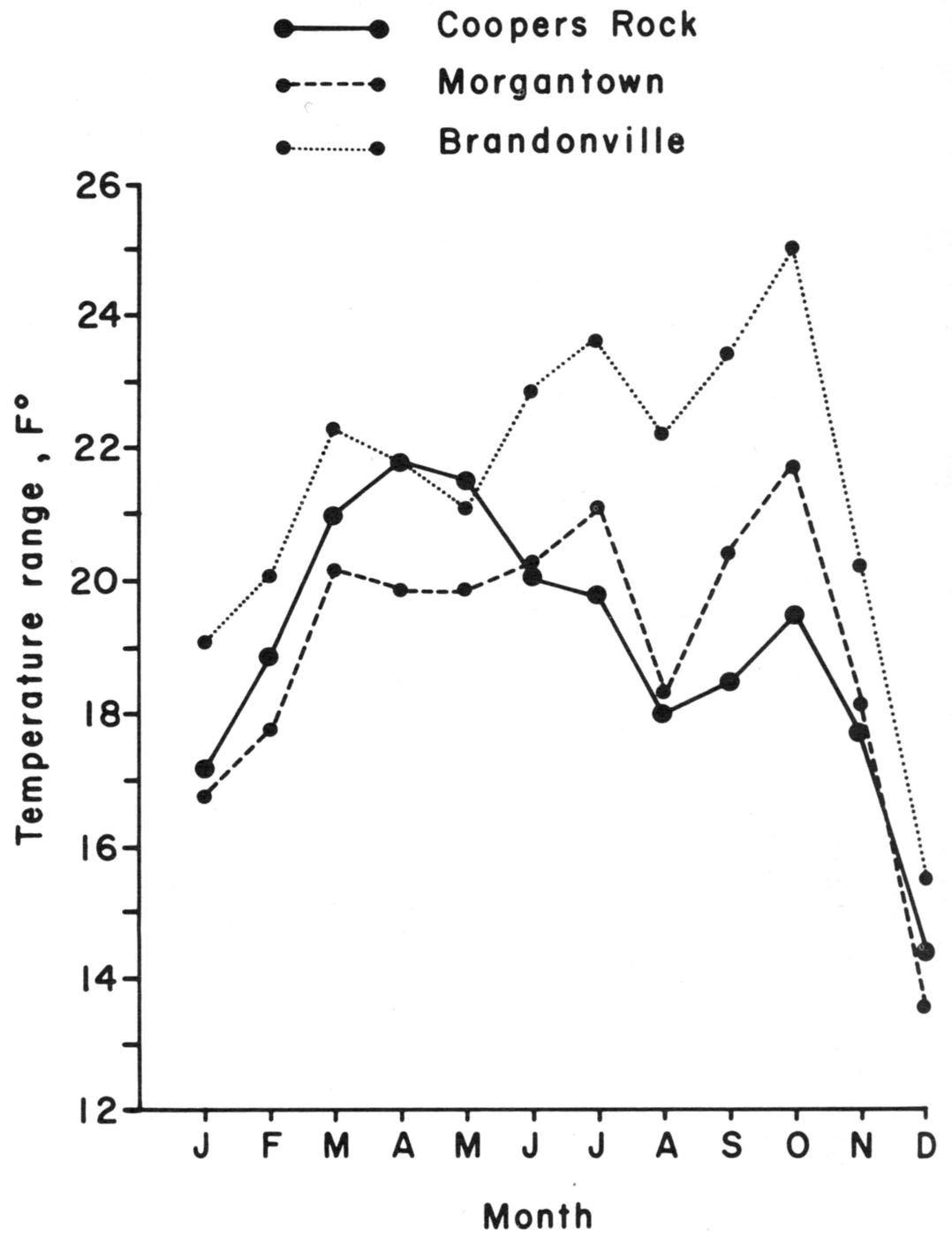

Figure 16. Mean diurnal ranges of air temperature by months at Morgantown, Brandonville, and Coopers Rock. 

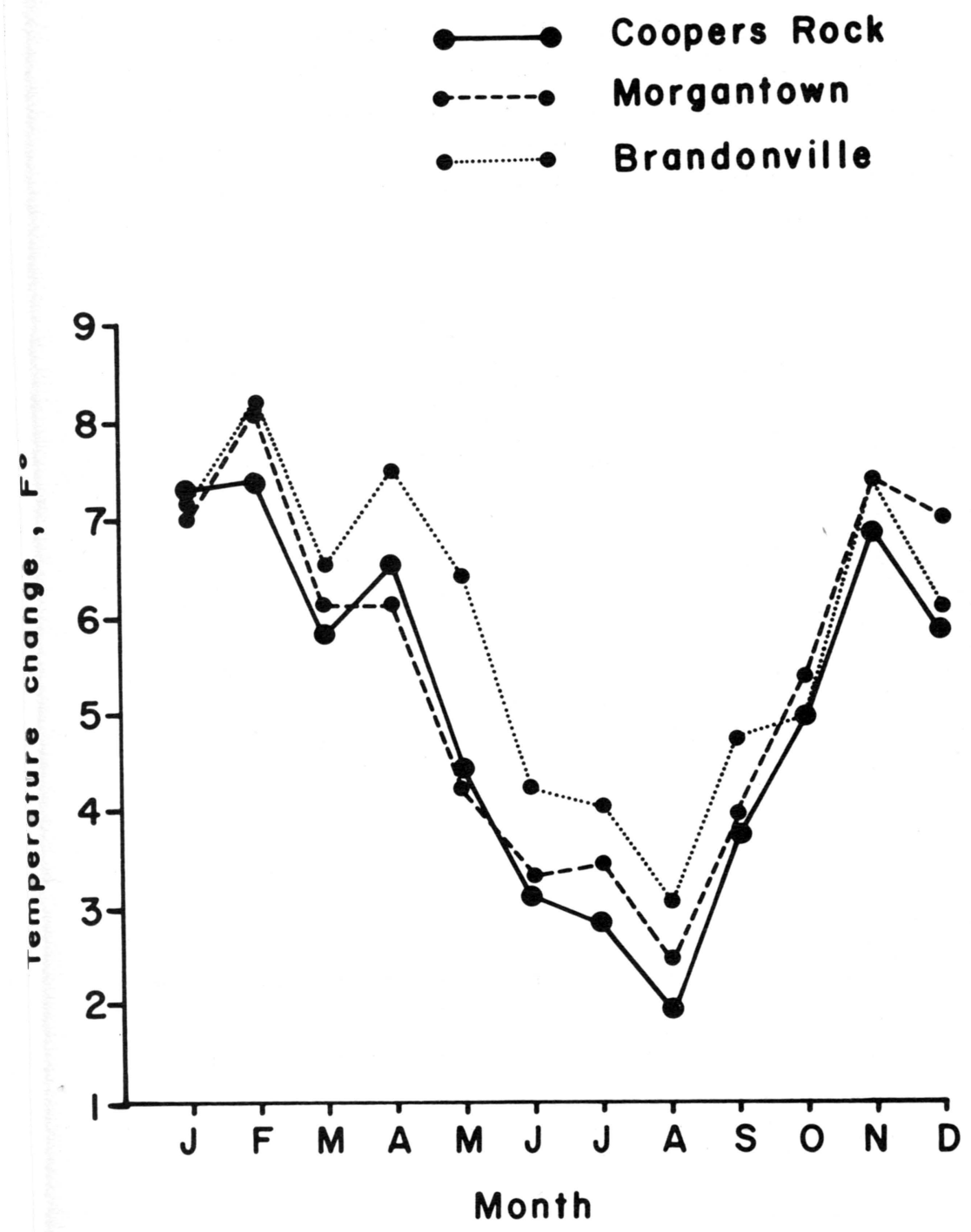

Figure 17. Average interdiurnal changes in mean air temperature by months at Morgantown, Brandonville, and Coopers Rock. 
TABLE 8. Wind Speed (miles/day) and Pan Evaporation (inches/day) at Coopers Rock During Summer 1973-1974

\begin{tabular}{lccccc}
\hline \hline Month & $\begin{array}{c}\text { Number } \\
\text { of days }\end{array}$ & $\begin{array}{c}\text { Wind speed } \\
\text { (Mean Maximum) }\end{array}$ & $\begin{array}{c}\text { Evaporation } \\
\text { (Mean Maximum) }\end{array}$ \\
\hline 1973 & & & & & \\
June & 29 & 17.8 & 35 & 0.143 & 0.23 \\
July & 31 & 16.7 & 43 & 0.128 & 0.25 \\
Aug. & 31 & 11.1 & 33 & 0.102 & 0.28 \\
Sept. & 30 & 16.3 & 43 & 0.093 & 0.17 \\
Oct. & 18 & 20.8 & 41 & 0.069 & 0.14 \\
& & & & & \\
1974 & 30 & 28.6 & 52 & & \\
May & 28 & 23.2 & 49 & 0.110 & 0.23 \\
June & 31 & 19.4 & 56 & 0.116 & 0.34 \\
July & 30 & 18.5 & 37 & 0.136 & 0.24 \\
Aug. & 22 & 19.9 & 47 & 0.095 & 0.19 \\
Sept. & 2 & & & 0.067 & 0.17 \\
\hline
\end{tabular}

TABLE 9. Relative Humidity, Temperature, and Ambient Vapor Pressure at Coopers Rock During January and July

\begin{tabular}{lcccc}
\hline \hline Parameter & \multicolumn{2}{c}{$\begin{array}{c}\text { January } \\
\text { Standard Dev. }\end{array}$} & Mean & $\begin{array}{c}\text { Suly } \\
\text { Standard Dev. }\end{array}$ \\
& & & & \\
\hline $\begin{array}{c}\text { Relative humidity (\%) } \\
\text { Maximum } \\
\text { Minimum }\end{array}$ & 83.8 & 15.1 & 97.0 & 4.5 \\
$\begin{array}{l}\left.\text { Temperature ( }{ }^{\circ} \mathrm{F}\right) \\
\text { At max RH } \\
\text { At min RH }\end{array}$ & 56.7 & 21.4 & 47.6 & 9.1 \\
& & & & \\
Ambient vapor pressure (mb) & 4.71 & 2.28 & 15.95 & 3.38 \\
\hline
\end{tabular}




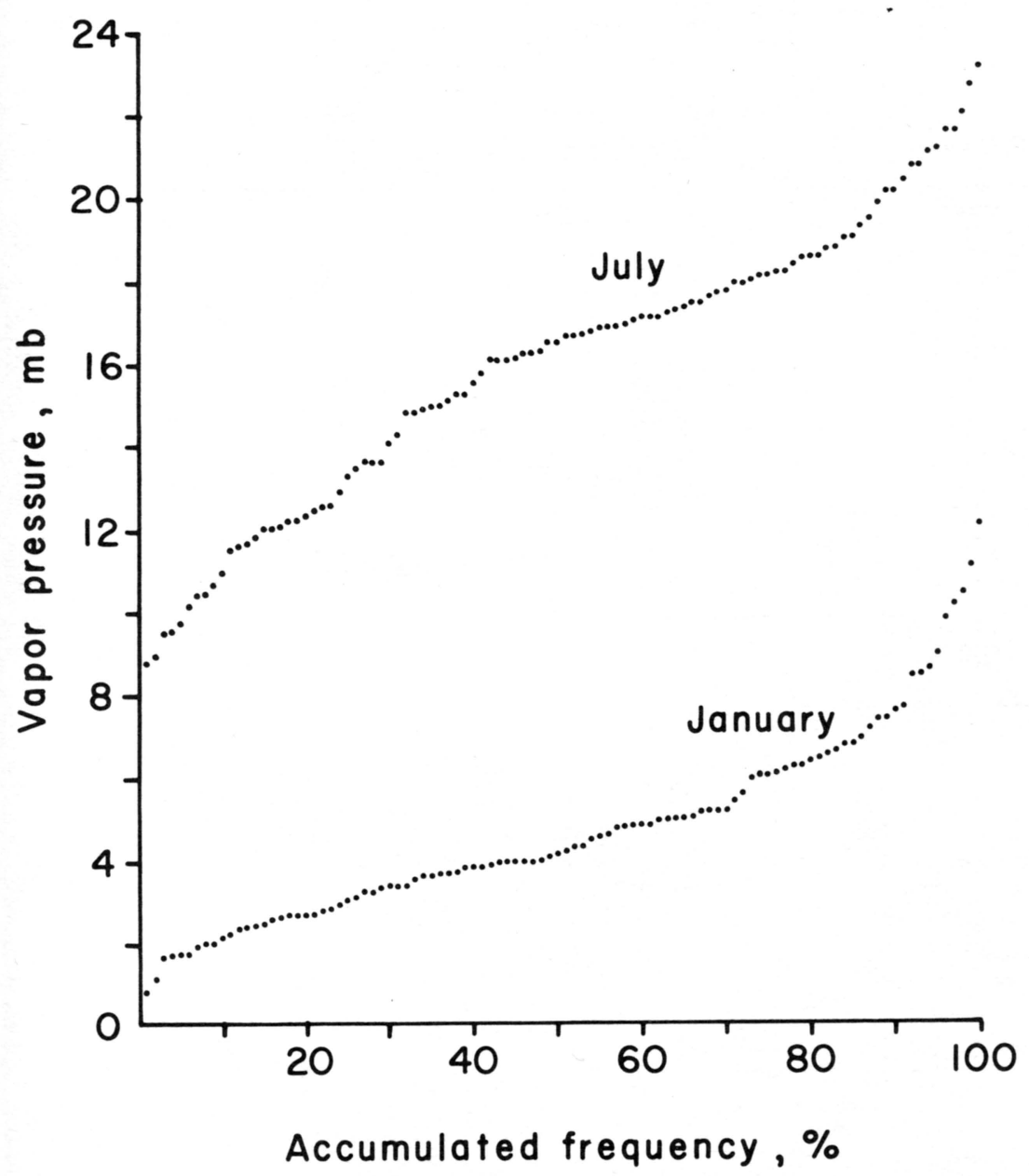

Figure 18. Accumulated frequencies of ambient vapor pressure at Coopers Rock during January and July.

On an average day in January, e $=4.7 \mathrm{mb}$, and evaporation can occur only if the temperature at the evaporating surface exceeds $25.7^{\circ} \mathrm{F}\left(e_{\mathrm{s}}=4.7 \mathrm{mb}\right)$. This means that direct sublimation from snow can occur only within the restricted range of temperature from 25.7 to $32^{\circ} \mathrm{F}$. At night, of course, or at any time that the surface temperature falls below $25.7^{\circ} \mathrm{F}$, condensation will occur and increase the snow mass. 
TABLE 10. Saturation Vapor Pressure $\left(e_{s}\right)$ as a Function of Temperature ( $T$ )

\begin{tabular}{rrrr}
\hline \hline $\mathbf{T}\left({ }^{\circ} \mathrm{F}\right)$ & $\mathbf{e}_{\mathbf{s}}(\mathrm{mb})$ & $\mathbf{T}\left({ }^{\mathbf{O}} \mathrm{F}\right)$ & $\mathrm{e}_{\mathbf{s}}(\mathrm{mb})$ \\
\hline-10 & 0.94 & 45 & 10.2 \\
-5 & 1.20 & 50 & 12.3 \\
0 & 1.52 & 55 & 14.8 \\
5 & 1.91 & 60 & 17.7 \\
10 & 2.39 & 65 & 21.1 \\
15 & 2.99 & 70 & 25.1 \\
20 & 3.71 & 75 & 29.7 \\
25 & 4.59 & 80 & 34.9 \\
30 & 5.63 & 85 & 41.1 \\
32 & 6.11 & 90 & 48.1 \\
35 & 6.89 & 95 & 56.2 \\
40 & 8.39 & 100 & 65.5 \\
\hline
\end{tabular}




\section{LITERATURE CITED}

Chang, M. 1973. Effects of topography and site exposure on precipitation distribution in mountainous areas. Ph.D. Dissertation, West Virginia University, Morgantown. 150 pp.

Chang, M., and R. Lee. 1974. Do forests increase precipitation? West Virginia Forestry Notes 2, pp. 16-20.

Chang, M., and R. Lee. 1975. Representativeness of watershed precipitation samples. Water Research Institute Bulletin 4, West Virginia University, Morgantown. 46 pp.

Geiger, R. 1965. The climate near the ground. Harvard University Press, Cambridge, Massachusetts. $611 \mathrm{pp}$.

Grafton, C. R. and W. H. Dickerson. 1969. Influence of topography on rainfall in West Virginia. Water Research Institute Bulletin 1, West Virginia University, Morgantown, 45 pp.

Landsberg, H. 1968. Physical climatology. Gray Printing Co., Dubois, Pennsylvania. 446 pp.

Lee, R. 1968. Latitude, elevation, and mean temperature in the Northeast. The Professional Geographer XXI(4): 227-231.

Lee, R. 1972. An optographic technique for evaluating the exposure of precipitation gage sites in mountainous areas. Proceedings WMO Symposium on the Distribution of Precipitation in Mountainous Areas (Geilo, Norway), Vol. II, pp. 62-72.

Penman, H. L. 1963. Vegetation and hydrology. Technical Communication 53, Commonwealth Bureau of Soils, Harpenden, England. $124 \mathrm{pp}$.

U. S. Department of Commerce. 1970. Weather Bureau Observing Handbook No. 2, Substation Observations. Data Aquisition Division, Office of Meteorological Observations, Silver Spring, Maryland. 77 pp. 
Blank Page in Original Bulletin 
Blank Page in Original Bulletin 
Blank Page in Original Bulletin 